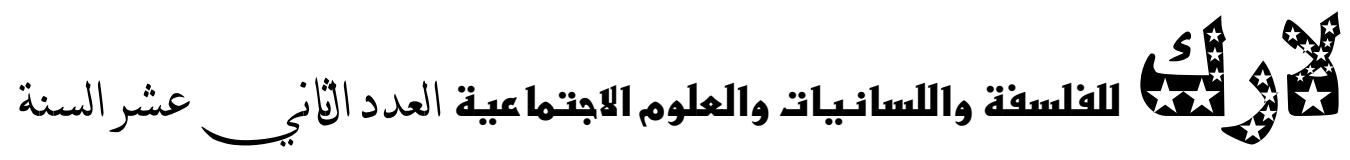

الخامسة2013

\title{
السلوك العدواني لاى طلبة المرحلة الاعدادية
}

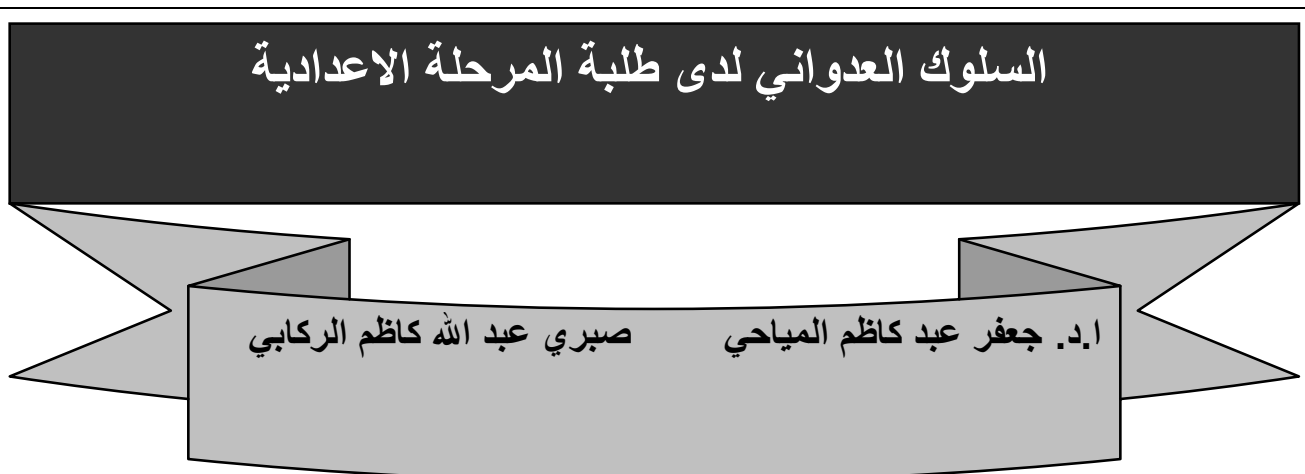

مشكلة البحث :

تشغل ظاهرة العدوان اهتمام الباحثين في مجالات العلوم الانسانية بصفة عامة وعلم النفس عالمان

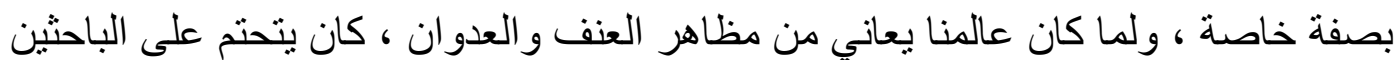
الغوص في أعماق هذه الظو اهر ، ولقد اختلفت وجهات ولفات النظر في شرح و وتفسير السلوك العدواني

وكان من نتيجة ذلك لم تخرج عن اتجاهات رئيسة هي : أما قوة فطرية استعدادية أو مثثيرات خارجية أو ارتباطات شرطية مقرونة بنماذج التعلم الاجتماعي.

(5: (أبو قوره ، 1996$)$

ومما لاشك فيه أن السلوك العدو اني لدى طلاب المدارس أصبح حقيقة واقعية موجودة في

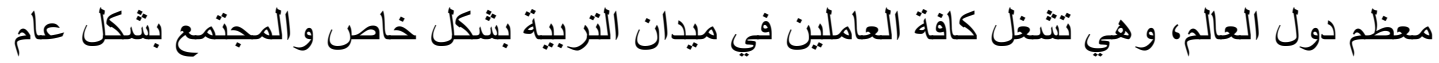

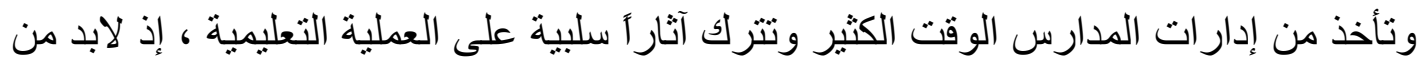

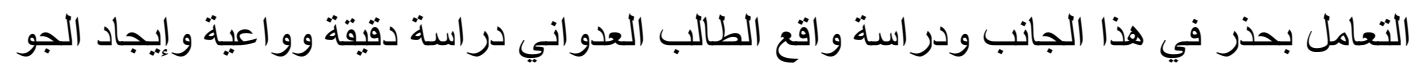

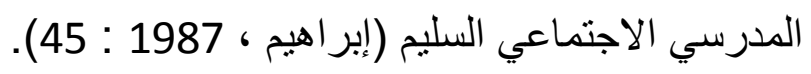

كما أن شيوع ثقافة العنف وما يرتبط بها من مظاهر القتل و التدمير وسفك الدماء ، قد شكل

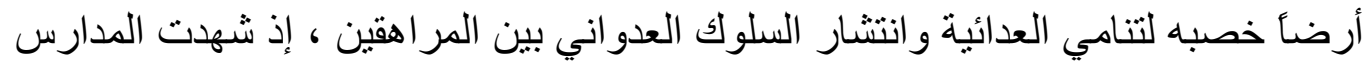

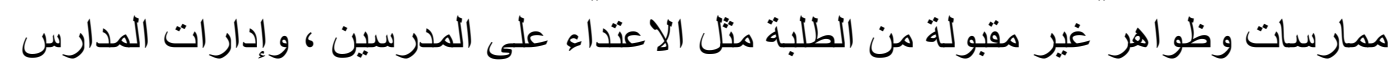

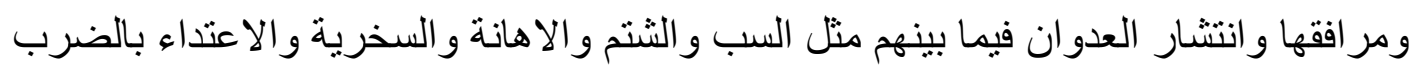

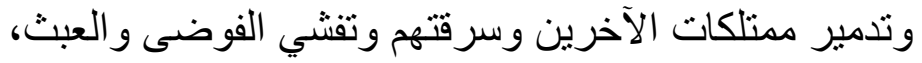

(الفتلاوي ، 2010 (5) (5)

وبناءاَ على ماتقدم تكمن مشكلة البحث الحالي في التساؤلات الاتية: 


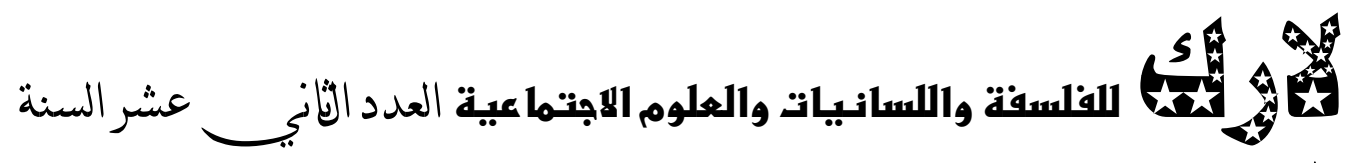

الخامسة2013

1 - ما مستوى السلوك العدواني لدى طلبة المرحلة الاعدادية.

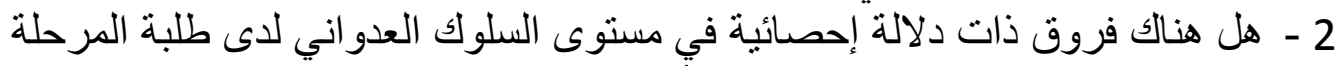

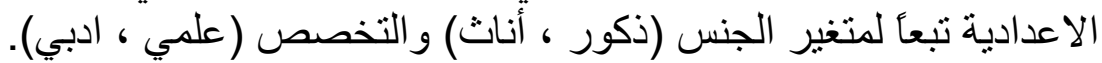

أهمية البحث : n

أن مرحلة المر اهقة من المر احل العمرية الحرجة التي يمر بها المر اهق ، فقد طرات

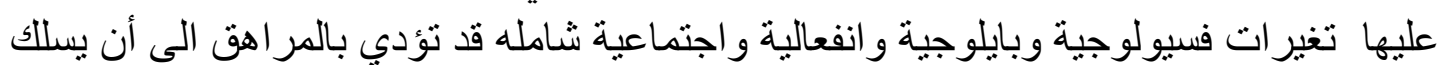

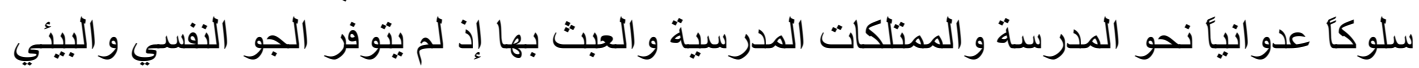

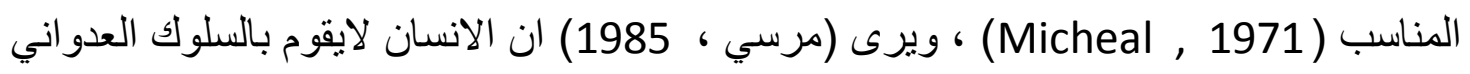

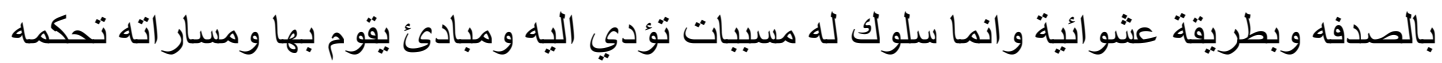

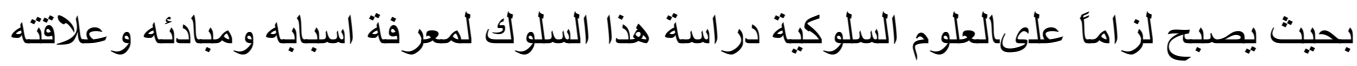

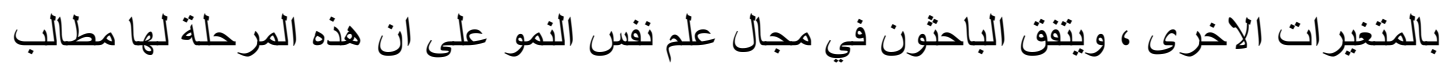

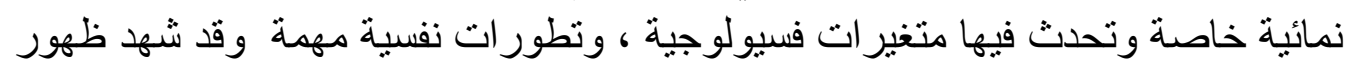

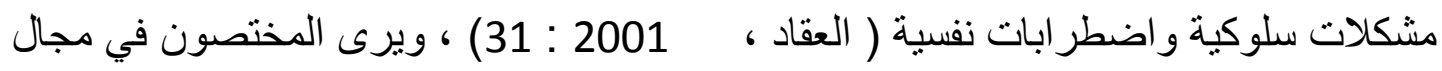

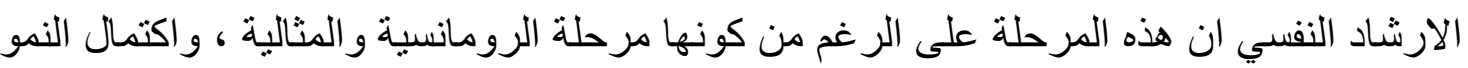

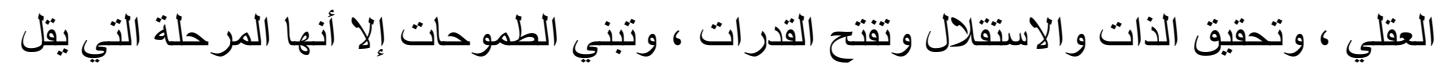

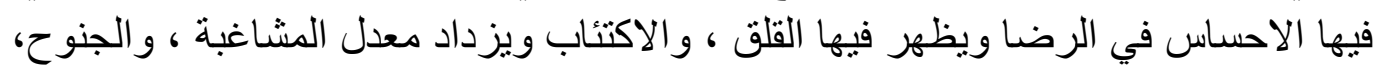
و تثهد حالات الانتحار ، و الادمان بكل اشكاله على العقاقير ، و التدخين ، وتنامي المشاكل العدائية

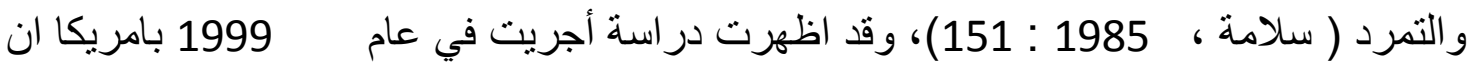
(77\%) من أفر اد العينة يشعرون بالقلق حول من مدارسهم ، ونتشير بعض الاحصائيات هنالك ان ان

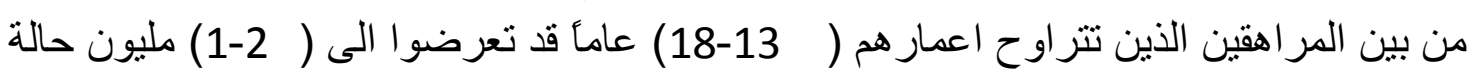
عنف في المدرسة ولا يستبعد ان تكون هذه المعدلات قد ازدادت في الاعو ام اللاحقة (العيسوي ،

.(36: 2007

كما أن معدلات انتشار السلوكيات العدوانية ترتفع بين أوساط الاطفال و المر اهقين سواء

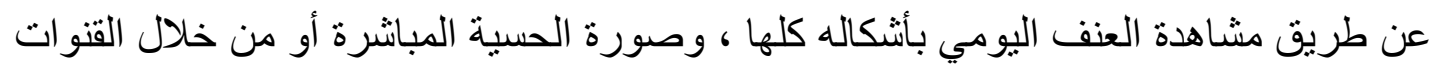
الفضائية و التكيف مع هذه المشاهد و التعود عليها ، و إمكانية تعلمها اجتماعياً من خلال تقليد الكبار ومحاكاتهم او مشاركتهم فيها في بعض هذه الاحيان.

وقد تتامى اهتمام المجتمعات اهتمام المجتمعات المتطورة و النامية بدر اسة ظاهرة العدوان

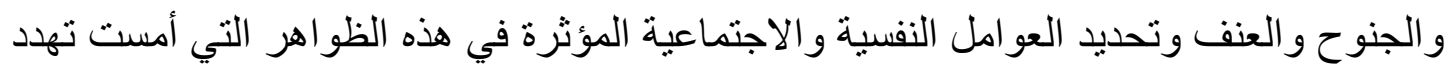
البناء النفسي للأفر اد و المجتمعات ، فقد وجد في الولايات المتحدة انه في كل عام يمثل أمام 


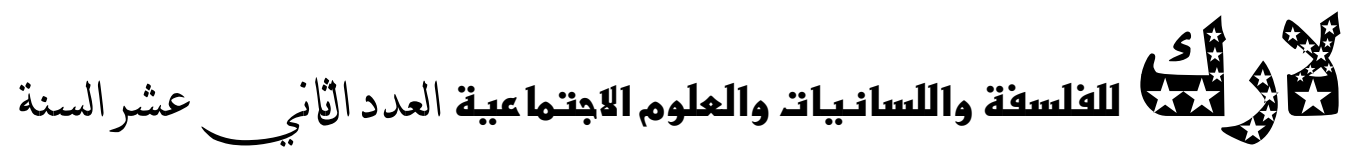

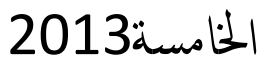

المحاكم اكثر من (750) الف طفل بتهمة الجنوح وان من بين كل خمسة اطفال هناك طفل يمثل

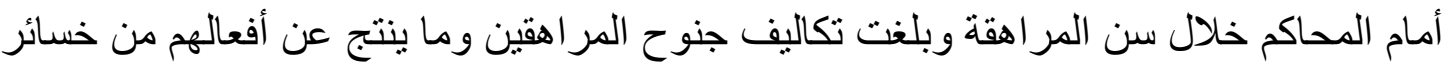

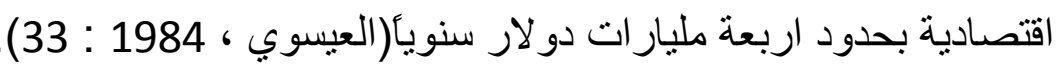

و على ضوء ماتقدم تبرز أهمية البحث الحالي في النقاط الآتية:

1- تأتي أهمية الدراسة من خلال أهمية متغير ها فهو السلوك العدو اني الذي يشكل مشكلة نفسية

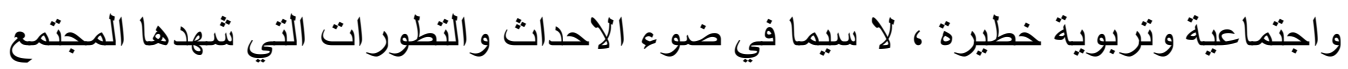

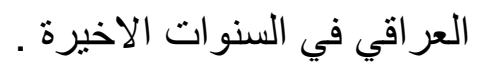

2- تمثل الفئة المستهدفة في الدراسة الحالية مرحلة عمرية تتسم بالأزمات و الصر اعات وتحدث

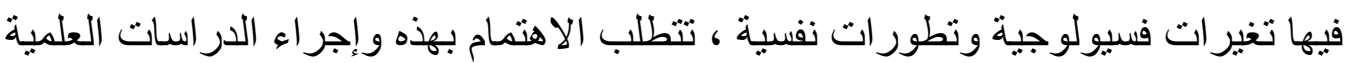
عiه 3- تساهم الدراسة في نشر الأساليب التربوية السليمة الواجب أتباعها مع الطلبة لاسيما شريحة المر اهقين وبيان الآثار السلبية لتجنبها وتعزيز الإيجايبة منها.

$$
\text { يستهدف البحث الحالي التعرف على : }
$$

1 - التعرف على مستوى السلوك العدو اني لدى طلبة المرحلة الإعدادية.

2 - تعرف دلالة الفروق في مستوى السلوك العدو اني لدى طلبة المرحلة الإعدادية تبعاً لمتغير

$$
\text { الجنس (ذكور ، إناث). }
$$

3- تعرف دلالة الفروق في مستوى السلوك العدو اني لدى طلبة المرحلة الإعدادية تبعاً لمتغير التخصص (علمي، أدبي).

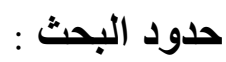
يتحدد البحث الحالي بطلبة الصف الرابع في المرحلة الإعدادية (علمي، أدبي) في مركز مدينة الكوت الدراسة الصباحية للعام الدر اسية (2012 - 2013). 
الخامسة

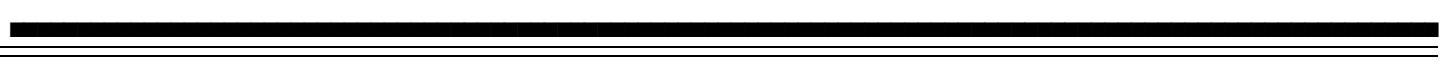

تحديا المصطلحات :

$$
\text { السلوك العدواني }
$$

ـ ـ لغوياً :

جاءت كلمة العدوان من الفعل (عدا) يقال عدا فلان عدواَ و عدوانأ وعداءً أي ظلك ظلماً جاوز فيه القدر.

$$
\begin{aligned}
& \text { العادي : الظالم و أصله من تجاوز الحد في الثيء. } \\
& \text { التعدي : مجاوزه الثيء الى غيره . }
\end{aligned}
$$

الاعتداء، و التعدي، و العدوان : الظلم. (أبن منظور، 2005 : 2573)

: -

1 - عرفه (Hilgard, 1990) نشاط هدام أو تخريبي، أو أي نوع من النشاط يقوم به الفرد

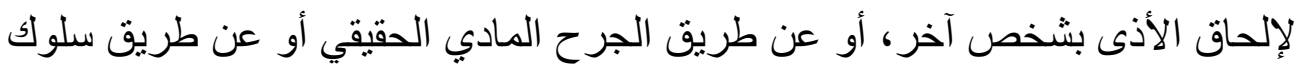

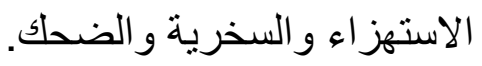

(عيسوي، 1990 : (ع59)

2 - و عرفه هاركافي (Harkvery, 1994) : بأنه سلوك يتسم بالهجوم البدني أو اللفظي.

(Harkvery, 1994, P:23)

4 - و عرفته باظة ( 2003) هجوم أو فعل محدد يتخذ أية صورة من الهجوم المادي و الجسدي و اللفظي، ويمكن أن يوجه ضد أي شيء، أو ممتلكات الذات و الآخرين أو الأفر اد بما فيهم

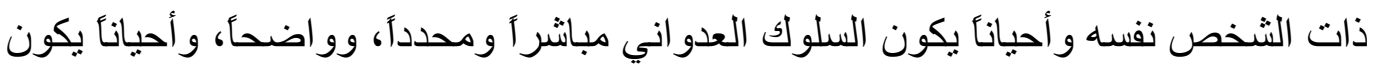




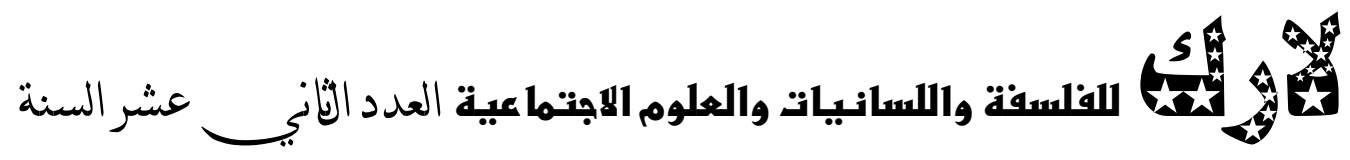
الخامسة2013

التعبير عنه بطريقة مباشرة، أو أسقاطية على الآخرين أو البيئة من حوله. (باظه، 2003 :

ـ التعريف النظري للسلوك العدواني : هوم أو فعل محدد يتخذ أية صورة من الهجوم المادي و الجسدي و اللفظي و المعنوي ، ويمكن أن يوجه ضد أي شيء، أو ممتلكات الذات و الآخرين.

ـ التعريف الإجرائي: هي الدرجة التي يحصل عليها الطلبة (أفراد العينة) على المقياس المتبنى في هذه الدر اسة.

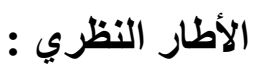

يعد السلوك العدواني أخطر ما يهدد أمن واستقرار و أفر اد المجتمع ، وخاصة ما يقع منه

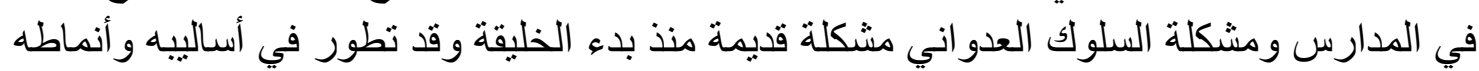
حتى وصل الى التحدي و القسوة من طلاف الأخرين وليس من طرف الذين يقومون به (آل رشود

(2: 2006 ،

فهو مشكلة متعددة الأبعاد إذ تتضمن أبعاد تربوية و أمنية ونفسية واجتماعية و اقتصادية وقد درس علماء النفس و المهتمين بالتربية و علماء الإجر ام و علماء الاجتماع أبعادها و أسبابها

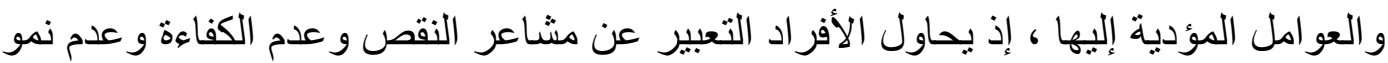

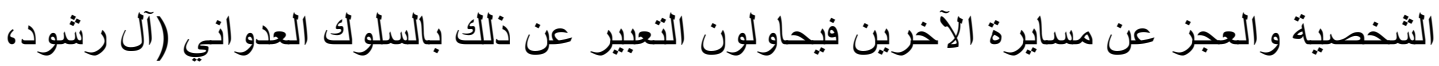

ويعلل بعض العلماء مشكلة العدوان بأنها أثنباع بطريث خاطئ منحرف لغريزتي المقاتلة

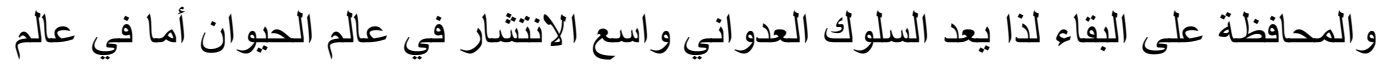

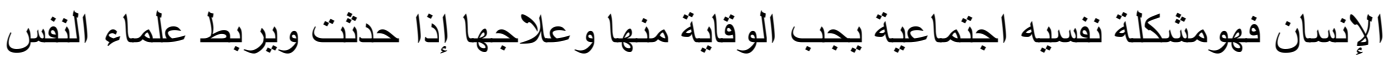
الفيزيولوجيون مظاهر العدوان بتغير ات جسمية داخلية كيمياوية ووظيفية عضوية ننشأ عن الجملة العصبية و الغدد و لاسيما الغدد فوق الكليوية (الهاتثمي، 2008 : 306).

يرى (فرويد) أن العدوان ينشأ من كبت الميول الجنسية ثم تطورت هذه الفكرة عنده

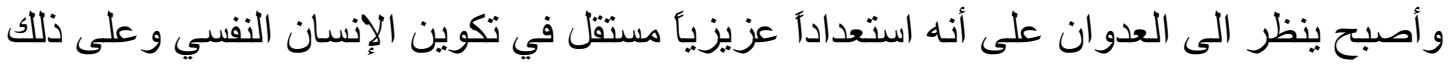

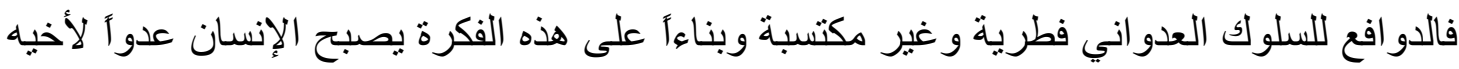

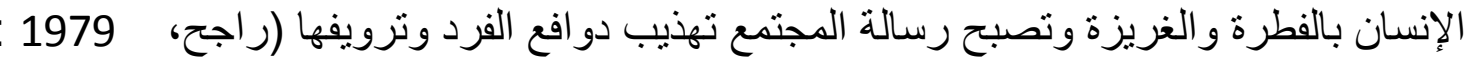




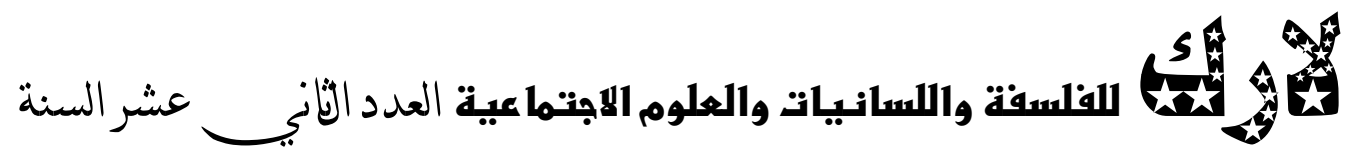

ويرى دو لارد و مساعدوه أن السلوك العدائي يسبقه دائماً حدوث إحباط عند الفرد

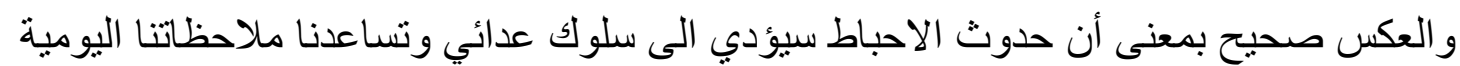

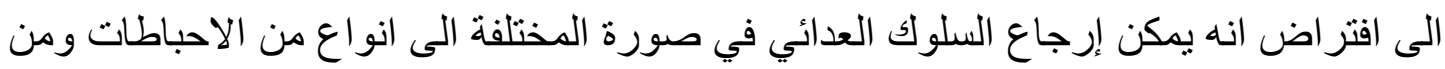

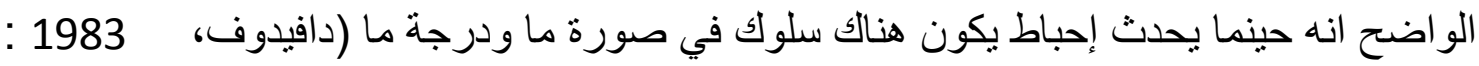

ويقسم العدوان الى العدوان المباثر وهو العدوان الذي يوجه مباشرة الى الثخص الذي آلثي

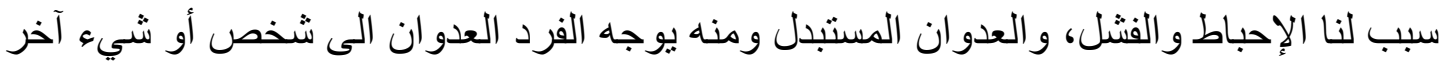

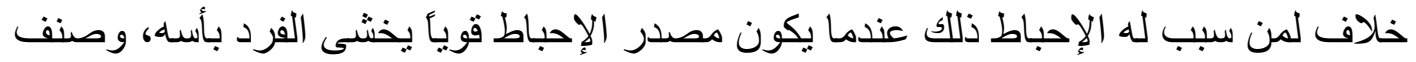

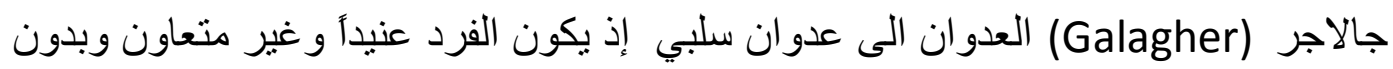

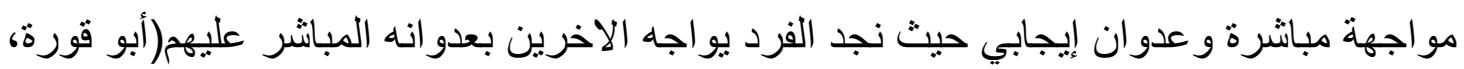
. 32 - 1996

فالعدو ان يكون سوياً إذا ما ارتقى بالقيم الأساسية الخاصة بالبقاء و السعادة و القبول

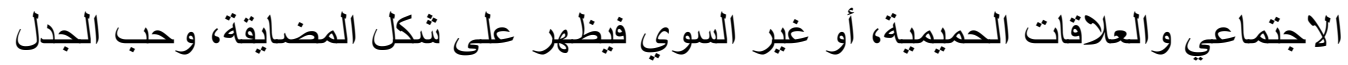

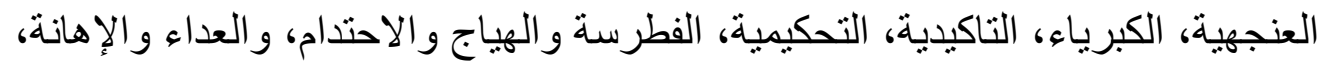
و المعارضة و العنف (Ellis, 1977, P:239) .

النظريات المفسرة للسلك العدواني : نظرية التعلم الاجتماعي :

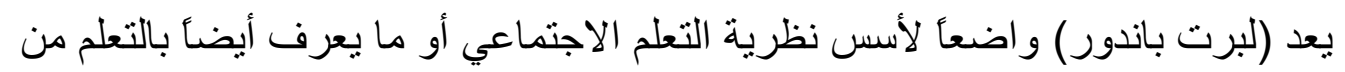

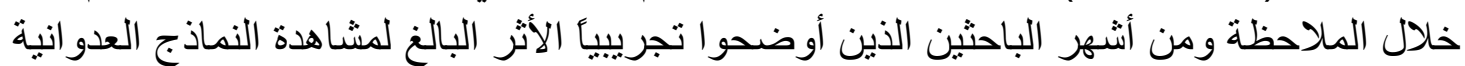

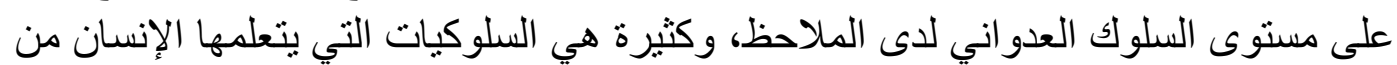

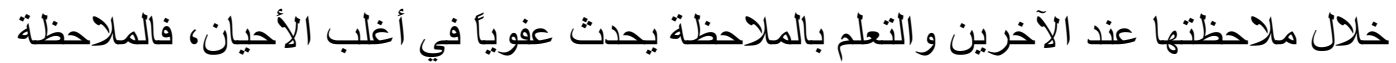

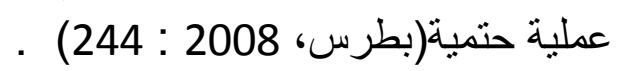

وتتلخص فكرة الملاحظة و التقليد بأن البيئة المحيطة تقدم للفرد نماذجأ كثيرةً من السلوك

و التي يقوم الفرد بدوره بتقليدها وهي ترم بالمر احل كالآتية:

1 - ملاحظة سلوك الآخرين (القدوة الاجتماعية) أو الانتباه .

2 - تذكر (Remembering) ما تم ملاحظته. 
الخامسة

3 - استعادة (Recall) الملاحظة من خلال المهارة الحركية (Motorskill) لما تم تذكره. 4 - التعزيز أو التدعيم (Rein Forment) المباشرة أو غير المباشر .

(الثيباني، 2000 : (66)

ان معظم السلوك العدو اني متعلم من خلال الملاحظة و التقليد من وجهة نظر باندور او هنالك عدة مصادر يمكن من خلالها تعلم السلوك العدو اني: ـ التأثثر الاسري الاخران ، النماذج الرمزية كالتلفزيون. ـ اكتساب السلوك العدواني من الخبرات السابقة. ـ التعليم المباشر للمسالك العدو انية كالاثارة المباثرة للافعال العدو انية الصريحة في أي وقت. ـ تأكيد هذا السلوك من خلال التعزيز و المكافأت. ـ الأثارة أما بالهجوم الجسمي بالتهديد أو الإهانات أو إعاقة سلوك موجه نحو هدف. (بطرس، 2008 2008 : (ب) - العقاب قد يؤدي الى زيادة العدوان.

نظرية العدوان الانفعالي Emotional Aggression :

يؤكد عدد كبير من علماء علم النفس الاجتماعي على وجود نوع من العدوان هدفه Hostility

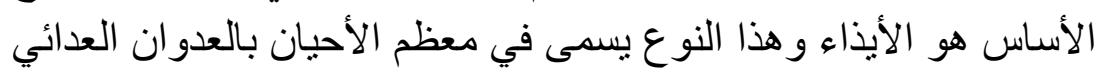

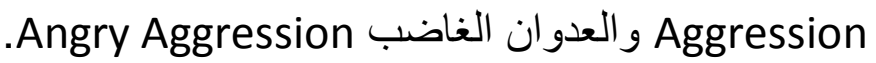

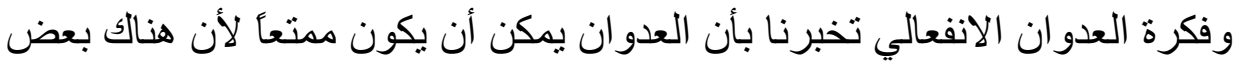

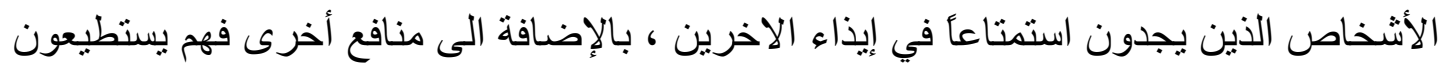
إثبات رجولتهم ويوضحون إنهم أقوياء وذو أهمية وإنهم يكتسبون الإنياء الإكانة الاجتماعية.

أن هذا الصنف يعززه عدد من الدو افع و الاسباب وأحد هذه الدوافع ان هؤلاء العدوانيين

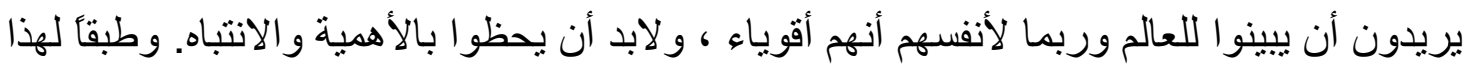

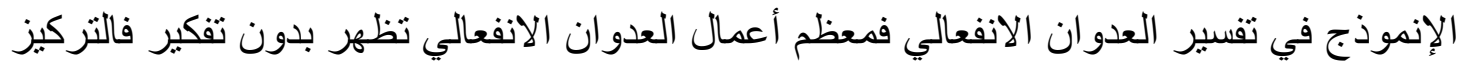




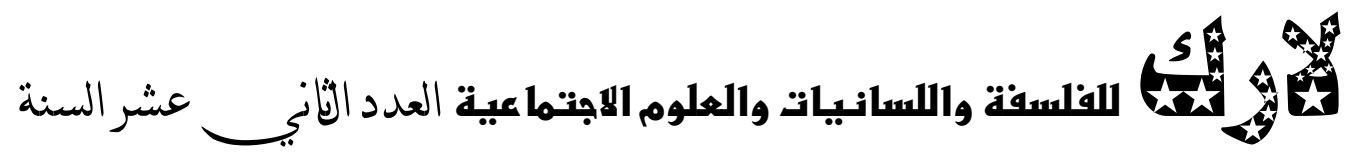

الخامسة2013

في هذه النظرية على العدوان غير المتسم نسبياً بالتفكير ويعني هذا خط الأساسي التي ترتكز

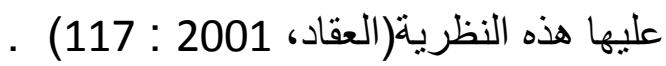

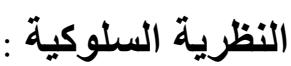

يرى السلوكيون أن العدوان شأنه شان أي سلوك يمكن أكتشافه ويمكن تعديله وفقاً لقو انين التعلم ،

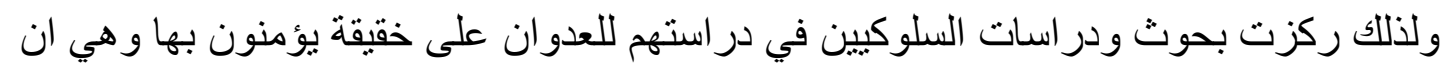

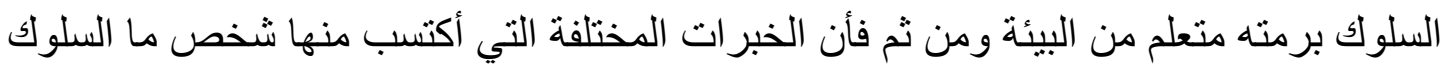

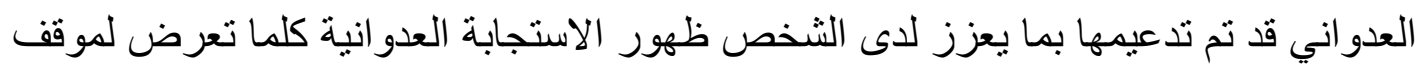

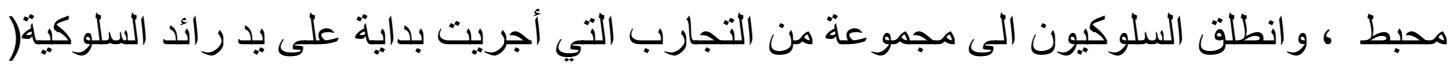

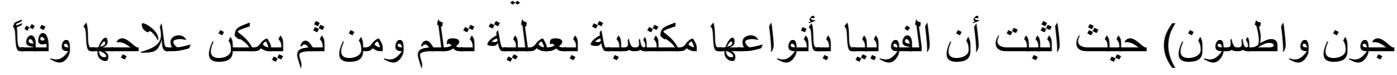
للعلاج السلوكي الذي يستند على هدم نموذج من التعلم غير سوي و إعادة بناء نموذج تعلم جديد سوي(بطرس، 2008 : 243).

مناقشة نظريات السلوك العدواني:

جاء تفسير السلوك العدواني على وفق نظرية (باندورا) على أن العدوان متعلم من خلال

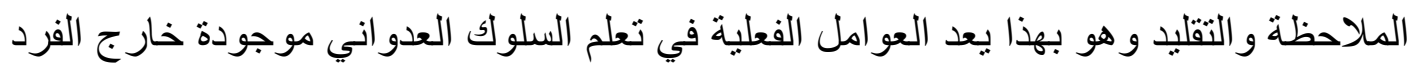

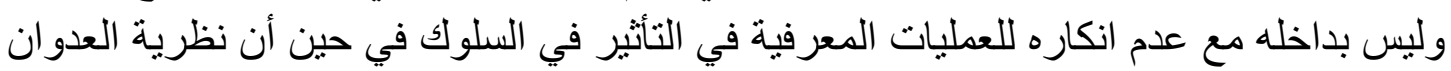

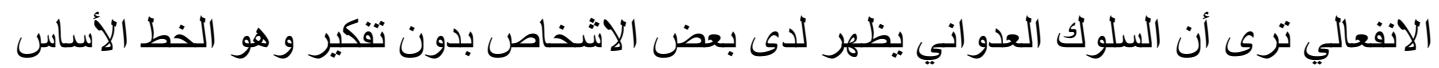

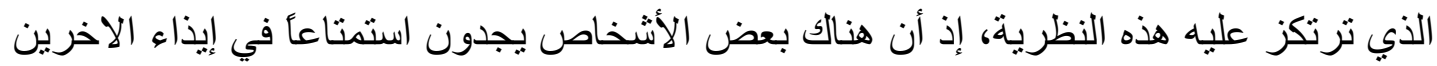

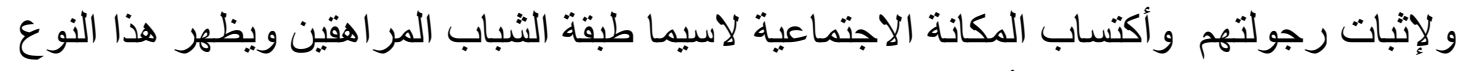
من العدوان مع استمر ار مكافأتهم على على عدوانهم .

أما النظرية السلوكية فترى ان السلوك متعلم من البيئة ويستمر إذا تم تدعيمه وتعزيزه

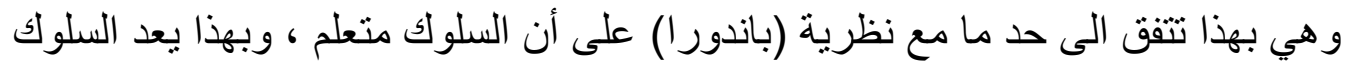

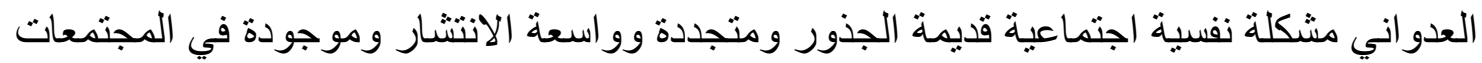
المتقدمة والمتخلفة وفي مختلف التقافات و الحضار ات وفي كل الأعمار لكنها أكثر انتشار آ في في الأني

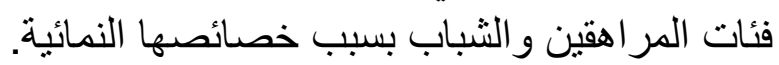
دراسات سابقة أولاً - دراسات عراقية :

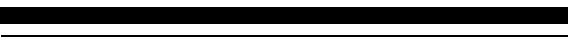




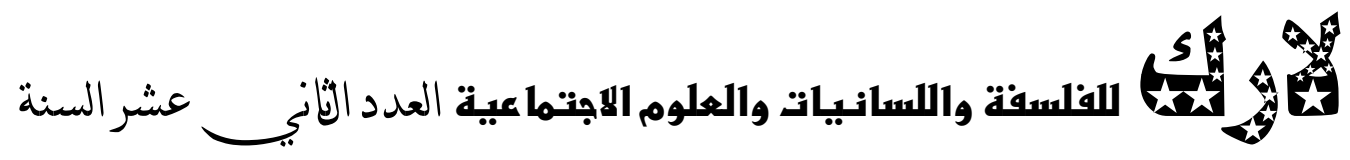
الخامسة2013

1 - دراسة الثمري (2003) : السلوك العدواني لاى طلبة المتوسطة في مدينة بغداد، دراسة

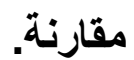

1 - أهداف الاراسة : قياس وكثف مستوى السلوك العدو اني عند طلبة المرحلة الهنوسطة تبعاً لمتغير الجنس ومستوى التحصيل الدر اسي للأم و الأب و الدخل الثهري للأسرة.

2 - عينة الدراسة : تألفت عينة الدراسة من ( 400) طالب وطالبة من طلبة الصف الثالث المنوسط بو اقع (220) طالبأ و (180) طالبة.

3 - ادوات البحث : قامت الباحثة ببناء مقياس قياس السلوك العدو اني مكون من ( 24) فقرة موزعة على مجالين هما : العدوان الحركي، العدوان اللفظي.

4 - الوسائل الإحصائية : استخدم الباحث الوسائل الإحصائية الآتية. الأختبار التائي لعينتين مستقلتين ومعامل ارتباط بيرسون ومعادلة سبيرمان.

5 - نتائج الدراسة : أظهرت نتائج الدراسة أن هناك فروقأ دالة إحصائياً بين الذكور والإناث ولصالح الذكور أي أنهم أكثر عدوانية من الإناث.

$$
\text { (الثمري، } 2003 \text { : } 51 \text { - } 50
$$

2 - دراسة الفتلاوي (2010) : السلوك العدواني وعلاقته بالذكاء الوجداني والتوافق النفسي والاجتماعي لطلبة المرحلة الإعدادية.

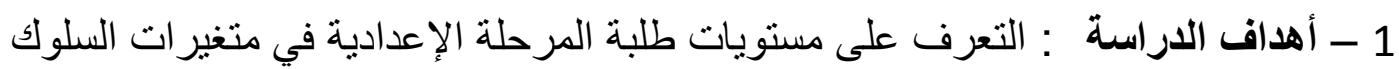

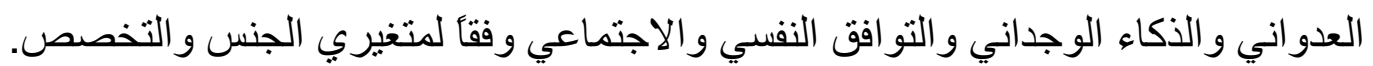
2 - عينة الدراسة : تألفت عينة در اسة البحث من ( 500) طالبأ وطالبة بواقع ( 275) طالباً و(225) وطالبة.

3 - أدوات الدراسة : تبنى الباحث مقياس (باظه) للسلوك العدواني ( 2003) وقام بناء مقياس

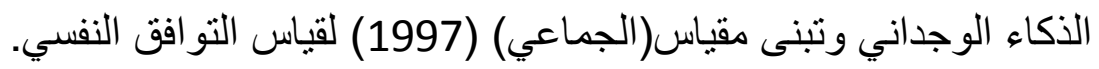

4 - الوسائل الإحصائية : استخدم الباحث الوسائل الإحصائية الآتية الوسط الحسابي و الانحر اف افتئي

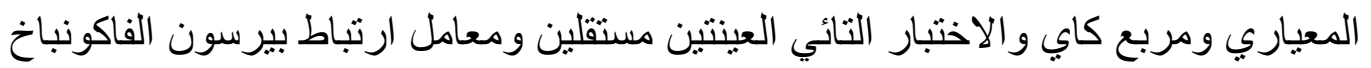
ومعامل الارتباط المتعدد. 


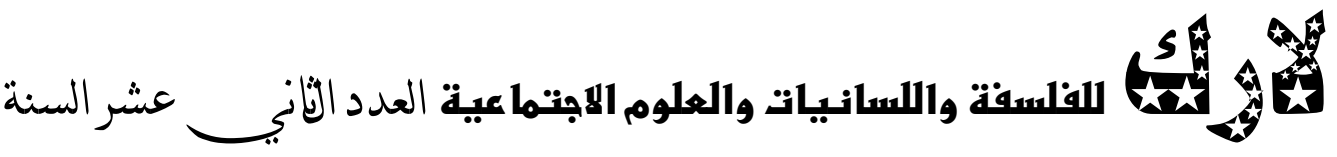
الخامسة2013

5 - نتائج الاراسة : أظهرت نتائج الدراسة أن مستويات السلوك العدواني بصفة عامة عند

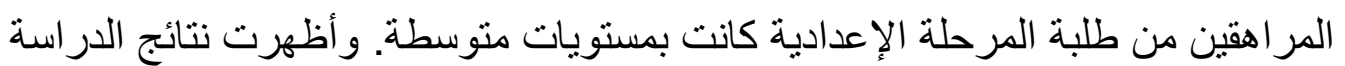

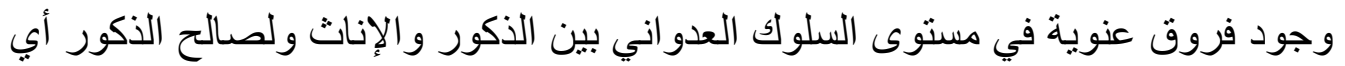

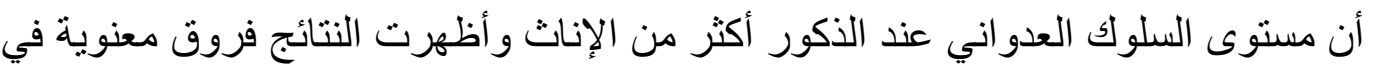

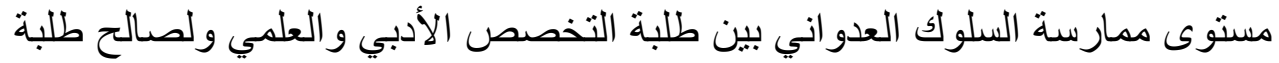
التخصص الأدبي أي أن طلبة الأدبي أكثر ممارسة للسلوك العدو العدي العي من طلبة العلمي.

$$
\begin{aligned}
& \text { (الفتلاوي، } 2010 \text { : } 118 \text { - 143). } \\
& \text { ب - دراسات عربية : }
\end{aligned}
$$

1 - دراسة أبو مصطفى والسميري (2007) : علاقة الأحداث الضاغطة بالسلوك العدواني. 1 - أهداف الدراسة : التعرف على علاقة الأحداث الضاغطة بالسلوك العدواني وكذلك التعرف

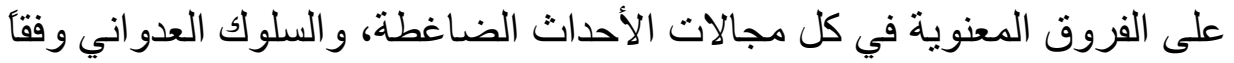
لمتغير ات الجنس و المستوى الدر اسي، والهيه والخلفية التقافية.

2 - عينة الدراسة : تألفت عينة البحث من ( 524) طالبأ وطالبة منها ( 188) طالبأ و( 336) طالبة.

3 - أدوات الدراسة : قام الباحثان بإعداد مقياس للسلوك العدواني يتألف من ( 39) فقرة موزعة

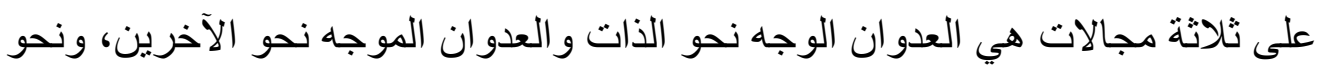
الممتلكات الجامعية.

4 - الوسائل الإحصائية : استعمل الباحثان برنامج (SPSS) الإحصائي بإيجاد الأوساط الحسابية و الانحر افات المعيارية والاختبار التائي، وتحليل التباين، ومعادلة شيفية للمقارنات الإنيج البعدية.

5 - نتائج الاراسة : كثفت نتائج الدر اسة أن العدوان الموجه نحو الذات احتل الترنيب الأول يليه العدوان الموجه نحو الآخرين فالعدوان الموجه نحو الممتلكات الجامعية، و أظهرت التهات النتائج

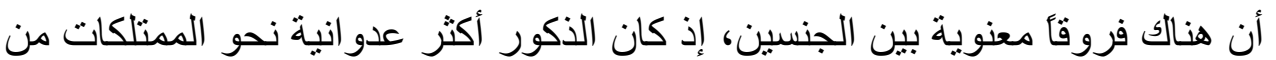
الإناث.

(أبو مصطفى و السميري، 2008 : (347) 
الخامسة

2- دراسة معمرية ( 2009) : أنماط السلوك العدواني، دراسة ميانية على عينة من المراهقين.

1 - أهداف الدراسة : التعرف على أبعاد السلوك العدواني الأكثر انتشار آ بين الشباب الجامعيين، و على الفروق بين الجنسين في أبعاد السلوك العدواني.

2 - عينة الدراسة : تألفت عينة البحث من ( 283) فرداً منهم ( 129) من الذكور و( 154) من الأناث و هم من الطلبة و الحرفيين و الموظهين.

3 - أدوات الدراسة: استخدم الباحث استبانة أعدها في در اسة سابقة لقياس السلوك العدواني وفقـ لتصنيف (أرنولد باص) المقسم الى أربعة أبعاد وهي : (العدوان البدني، العدوان النية اللفظي،

الغضب، العداوة).

4 - الوسائل الإحصائية : استخدام الباحث الوسائل الإحصائية الآتية : المتوسطات الحسابية و الانحر افات المعيارية و الاختبار التائي ومعامل الارتباط لبئ لبيرمان.

5 - نتائج الدراسة : أظهرت نتائج الدر اسة عن وجود اتفاق و اختلاف في شيوع أنماط السلوك العدو اني، ومن ثم تزيينها لاى الجنسين، و هناك فروق معنوية في الارجة الكلية للعدوان،

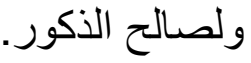
(286 : معدرية، 1999 (مع)

ج - دراسات أجنبية :

1 - دراسة بيسواز (Biswas, 1989) : اتجاه السلوك العدواني لدى المرهقين وعلاقته بالأسرة.

1 - أهداف الدراسة : استهدافت الدراسة السلوك العدو اني للطالب في المدرسة و علاقته بالأسرة. 2 - عينة الدراسة : تألفت عينة الدر اسة من (284) تلميذاً من عمر (8 - 15) سنة. 3 - أدوات الاراسة : تم استخدام اختبار السلوك واختبار ات الشخصية على عتبة البحث. 


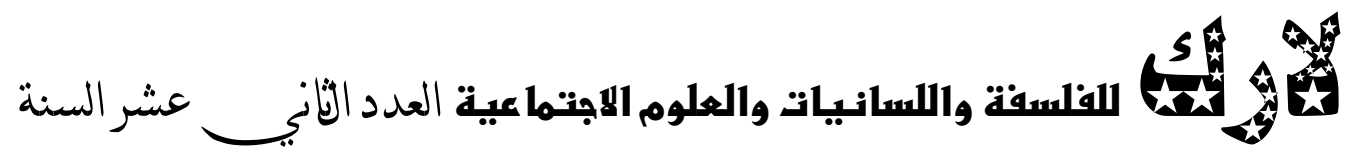
الخامسة2013

4 - الوسائل الإحصائية : تمت معالجة البيانات باستخدام تحليل التباين و المتوسط الحسابي و الانحر اف المعباري.

5 - نتائج الدراسة : أظهرت نتائج الدر اسة أن السلوك العدواني للتلميذ حيال أقر انه على علاقة وثيقة بالموقف الأسري المتوتر الذي تسودة الخلافات والصر اعات، وأن هذه العلاقة أثد وأوثق عند الذكور منها عند الأناث.

2- دراسة مونوز وآخرون (Monoz , et al, 2007) : العدوان البدني والنفسي لاى طلبة الجامعة.

1 - أهداف الدراسة : هدفت الدر اسة الى الكثف عن مظاهر العدوان البدني و النفسي لدى طلبة الجامعة في ظل علاقاتهم الجامعية.

2 - عينة الدراسة : تألفت عينة الدر اسة من ( 500) طالب وطالبة من طلبة الجامعة تنر اوح

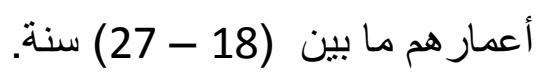

3 - أدوات الدراسة : استعمل الباحث مقياس السلوك العدواني لقياس مظاهر العدوان لدى طلبة الجامعة في ظل علاقاتهم الجامعية.

4 - الوسائل الإحصائية : تمت معالجة البيانات ما استخدام المتوسط الحسابي والانحر اف المعياري والاختبار التائي.

5 - نتائج الاراسة : أسفرت نتائج الدراسة عن انتشار عالي للعدوان الطبيعي والنفسي في

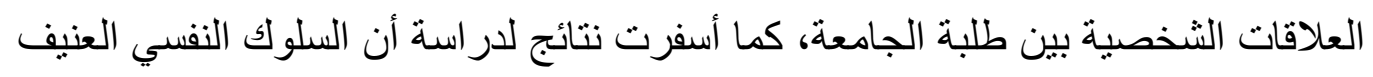

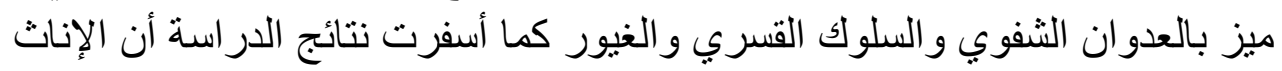

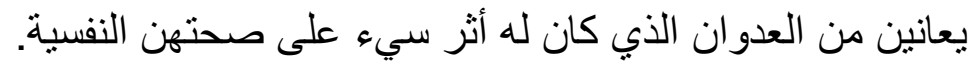

(Munoz, et al, P:107)

مناقشة الدر اسات السابقة :

بعد استعر اض الدر اسات السابقة يمكن مناقتنها ضمن المجاور التالية : 


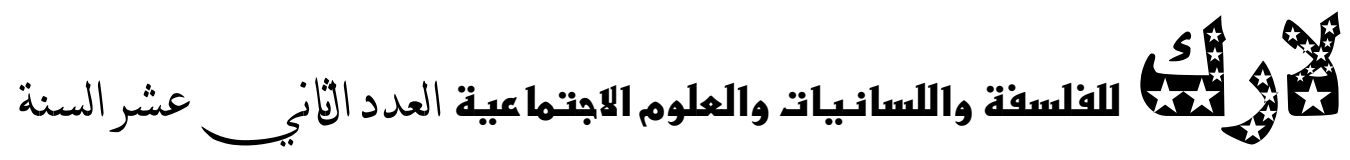

الخامسة2013

1 - الأهداف : لقد أتفقت الدر اسات السابقة في بعض أهدافها وأختلفت في البعض الآخر ، أما هدف البحث الحالي فهو التعرف على مستوى السلوك العدواني لاى طلبة المرحلة الاعدادية وفقأ لمتغير الجنس والتخصص.

2 - العينة : تباينت الدر اسات في إعداد عينتها ونو عها التي اختيرت منها فمن حيث النوع نرى

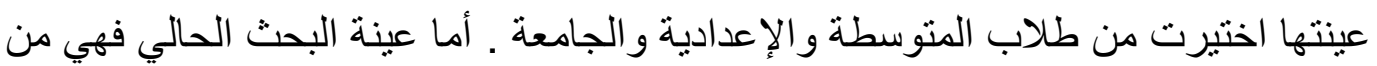

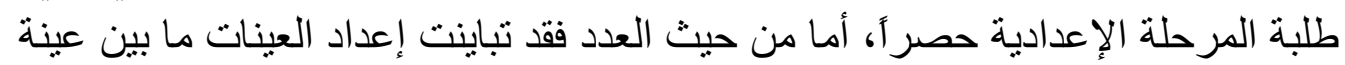
متوسطة بلغت ( 283) و عينة كبيرة بلغت ( 524) ، وحجم عينة البحث الحالي فقد بلغت (300) طالبً وطالبة.

3 - أدوات الدراسة : استخدمت الدر اسات السابقة أدوات تختلف بأختلاف أهدافها فقد استخدم

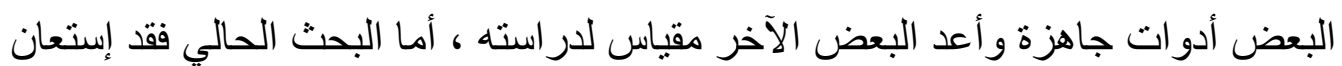
الباحث بمقياس السلوك العدو اني الذي استعمله (الفتلاوي، 2010) و المعد للمر اهقين.

3 - الوسائل الإحصائية : أستخدمت الدر اسات السابقة وسائل إحصائية مختلفة باختلاف أهدافها ،

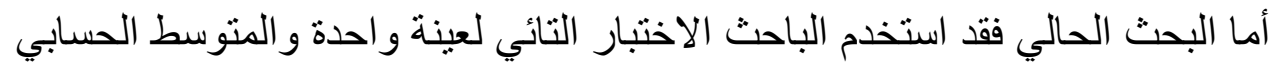

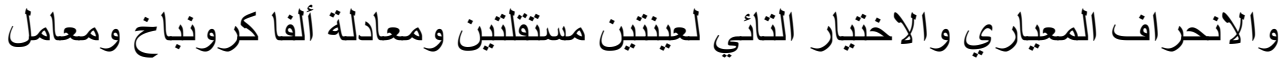
ارتباط بيرسون.

أما نتائج الدر اسات السابقة فكانت كالآتي:

توصلت در اسة (الفتلاوي ، 2010)أن مستويات السلوك العدواني بصفة عامة عند

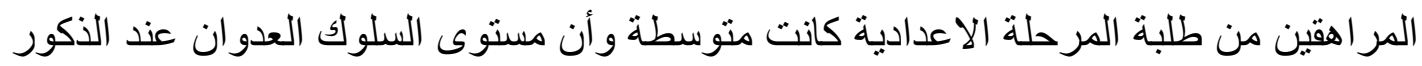

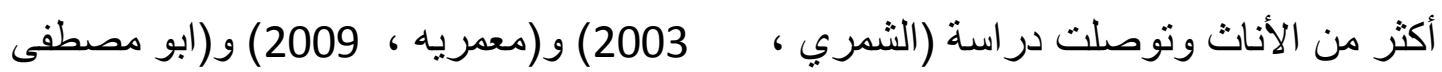

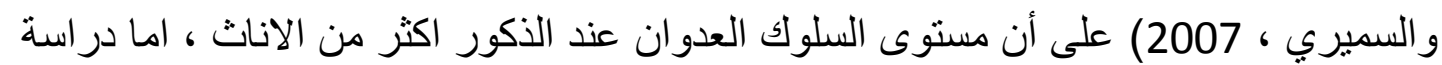

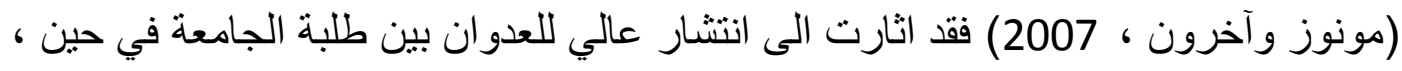

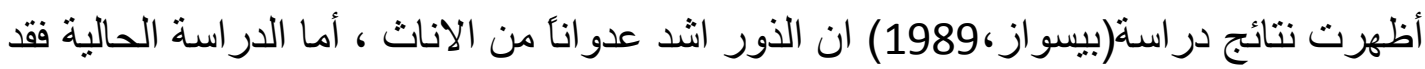

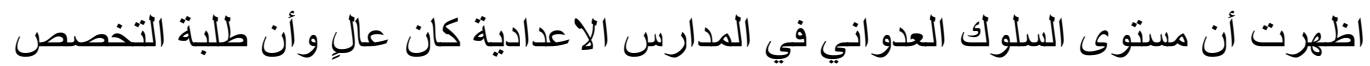


الخا مسنة

الادبي اعلى مستوى في السلوك العدو اني من طلبة التخصص العلمي ، واظهرت عدم وجود فروق في مستوى السلوك العدواني تبعاً لمتغير الجنس.

منهجية البحث وإجراعاته:

أولاًا : منهجية البحث

اتبع الباحثنان المنهج الوصفي كونه المنهج الذي بركز على وصف ماهو كائن في حياة

الانسان و المجتمع ، وأن هذا المنهج لايقتصر على جميع البيانات وثبوتها ، إنما بمضي الى ولى قدر

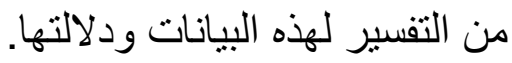

(حناو أنور، 1990:159)

ثانياً : مجتمع البحث

تحدد مجتمع البحث الحالي بطلبة الصف الر ابع في المدارس الثانوية والإعدادية الصباحية

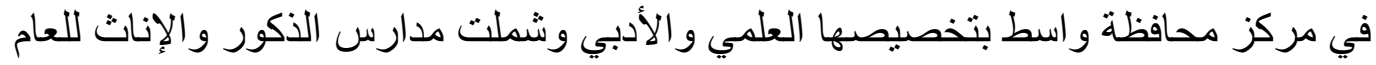

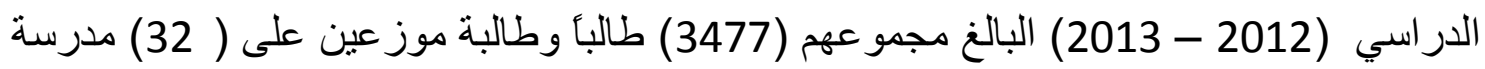

ثانوية و إعدادية بو اقع (20) مدرسة للبنات و(12) مدرسة للبنين (*)، كما موضح في الجدول رقم

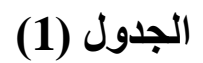

يوضح مجتمع البحث حسب إعداد المدارس والطلبة حسب (الجنس والتخصص)

(*) تم الحصول على هذه البيانات من قسم التخطيط التربوي في المديرية العامة لتربية واسط على ضوء كتاب تسهيل مهمة برقم (350) بتاريخ ل2013/1/21. 


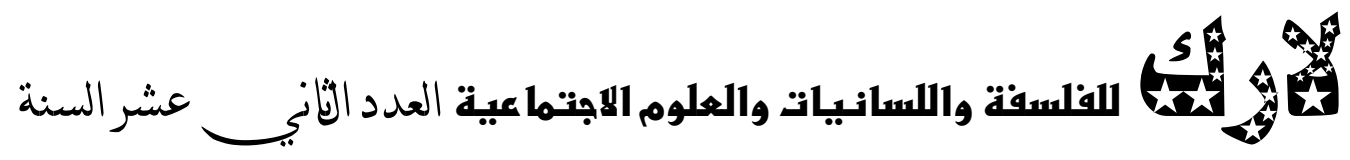
الخامسة2013

\begin{tabular}{|c|c|c|c|c|}
\hline \multirow{2}{*}{ مجموع الطلبة } & \multicolumn{2}{|c|}{ الصف الر ابع } & \multirow{2}{*}{ عدد المدارس } & \multirow{2}{*}{ المدارس } \\
\hline & الأدبي & العلمي & & \\
\hline 1761 & 718 & 1043 & 12 & بنين \\
\hline 1716 & 786 & 930 & 20 & بنات \\
\hline 3477 & 1504 & 1973 & 32 & المجموع \\
\hline
\end{tabular}

بلغت عينة البحث (300) طالبأ وطالبة من طلبة الر ابع الاعدادي الأدبي و العلمي وبنسبة (8.60\%) من المجتمع الأصلي البالغ عدده (3477) وتم اختبار هم بالطريقة العشو ائية.

رابعاً : أداة البحث

بعد أطلاع الباحث على المقاييس العر اقية والعربية وجد أن من المناسب تبني مقياس (الفتلاوي، 2010) و المأخوذ عن (باظة، 2003) وبالر غم من أن الفتلاوي لم بيند المقياس

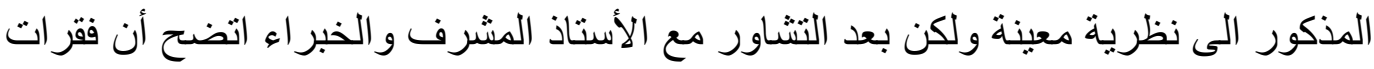

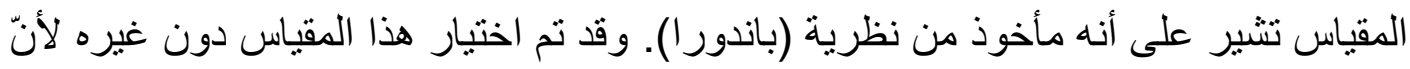

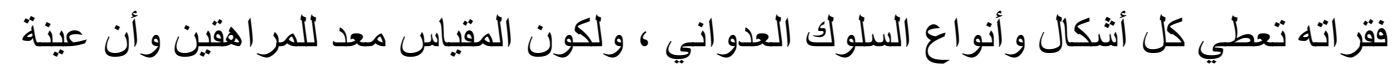
البحث الحالي هي من المر اهقين.

وصف المقياس :

يتكون المقياس من ( 52) فقرة تمثل كل واحدة منها استجابة سلوكية عدو انية يمارسها

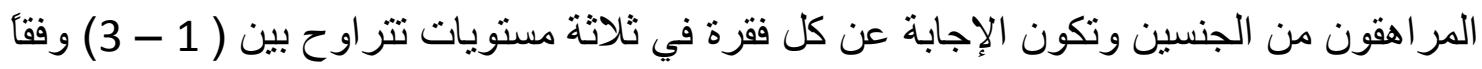

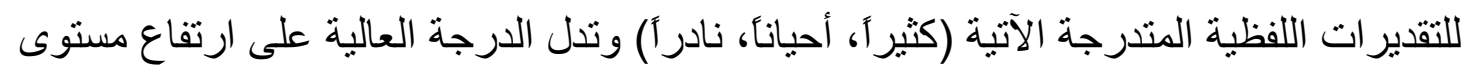
السلوك العدو اني والدرجة المنخفضة على انخفاض مستوى السلولك العدواني. ـ الخصائص السايكومترية لمقياس السلوك العدواني :

- Validity الصدق - 


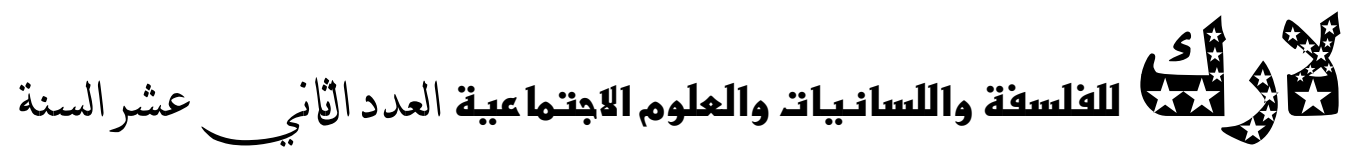
الخامسة2013

من الخصائص الأساسية التي لابد أن تتوافر في المقاييس النفسية والتربوية هما الصدق (Validity)

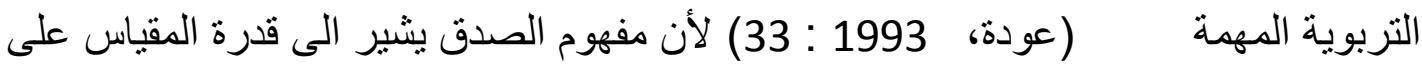

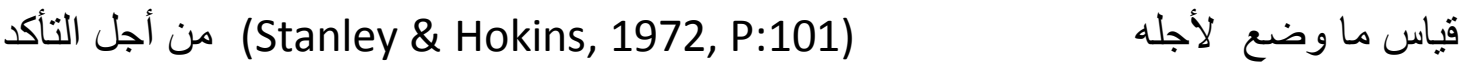
ن صدق المقياس فقد أعتمد الباحث الإجراء أهات الآثية :

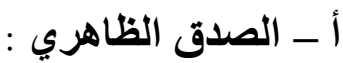

يشير المتخصصون في المجال النفسي أن أفضل وسيلة لتقرير الصدق الظاهري هو

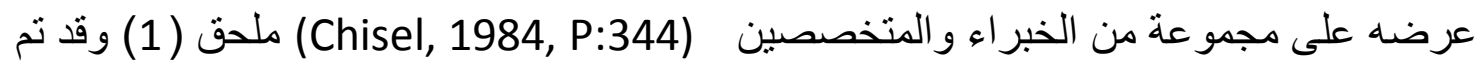
الأخذ بالملاحظات وفي ضوء هذا الإجراء ثم استبعاد (2) فقرة وبذلك يصبح عدد فقرات المقياس (50) فقرة بعد اتفاق أكثر من 80\% من المحكمين عليها.

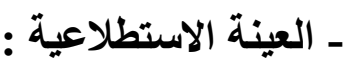

من أجل التأكد من مدى فهم الطلبة لعبار ات المقياس والتعرف على وضوح تعليماته قام

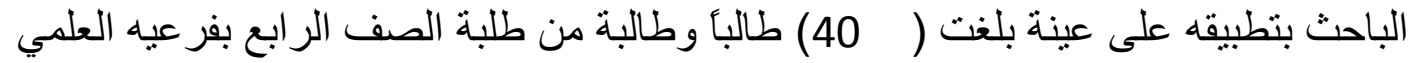
و الأدبي وقد تبين أن فقرات المقياس وتعليماته كانت و اضحة، وقد تراوح الوقت المستغرق للإجابة عن فقر اته ما بين (15 - 25) دقيقة. ـ التحليل الإحصائي لفقرات مقياس السلوك العدواني :

يعد التحليل الإحصائي للفقرات يعد أكثر أهمية من التحليل المنطقي لأن التحليل المنطقي

قد لا يكثف أحيانأ عن صلاحية مقاييس الشخصية بينما يكثف التحليل الإحصائي للارجات الإندية

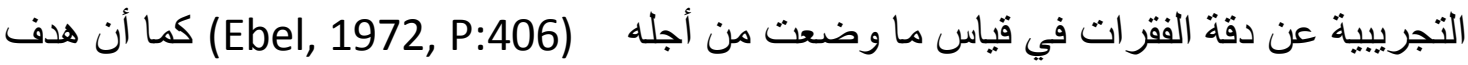

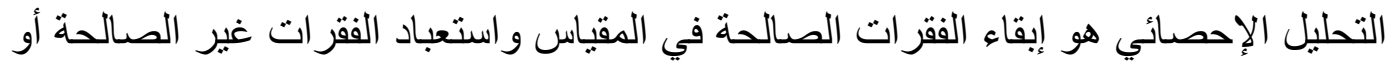
تعديلها (Guilford, 1954, P:417) تهو الإحس وقد تضمن التحليل الإحصائي ما يأتي : أ - - حساب القوة التميزية . ب - صدق الفقرات (معامل الاتساق الداخلي). 
الخامسة 2013

أ - ـ حساب القوة التمييزية :

قام الباحثان بحساب القوة التميزية لفقرات المقياس وذللك بتطبيق المقياس على عينة مؤلفة من (300) طالبأ وطالبة (عينة التحليل الإحصائي) موز عة على ست مدارس إعدادية وثانوية في

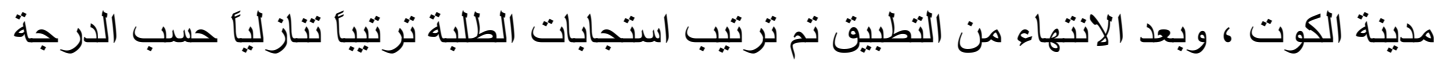

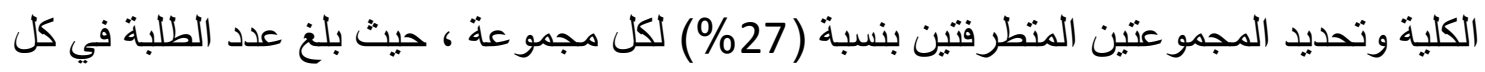

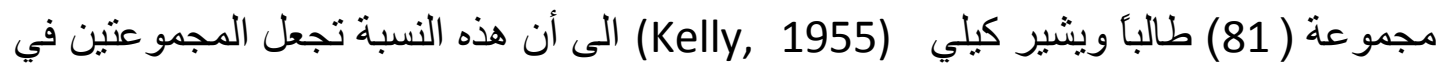
أفضل ما يكون في الحجم و التباين (Kelly, 1955, P:468) و استعمل الباحثنان الاختبار التائي لعينتين مستقلتين في معرفة دلالة الفروق بين متوسطي درجات المجمو عتين لكل فقرة، وكانت القيم التائية جميعاً دالة إحصائيا بمستوى دلالة (0.05) كما مبين في الجدول (2) (2).

جدول (2)

نتائج الاختبار التائي لعينتين مستقلتين لحساب قوة التمبيزية لفقرات مقياس العدواني

\begin{tabular}{|c|c|c|c|c|c|}
\hline \multirow{2}{*}{ القيمة التائية } & \multicolumn{2}{|c|}{ المجموعة الدنيا } & \multicolumn{2}{|c|}{ المجموعة العليا } & \multirow{2}{*}{ ل لفقرة } \\
\hline & الالانحراف & الوسط الحسابي & الانحر اف & الوسط الحسابي & \\
\hline 2.165 & 0.521 & 1.419 & 0.494 & 1.592 & 1 \\
\hline 2.493 & 0.802 & 1.592 & 0.707 & 1.888 & 2 \\
\hline 2.135 & 0.521 & 1.419 & 0.714 & 1.629 & 3 \\
\hline 4.289 & 0.718 & 1.691 & 0.851 & 2.222 & 4 \\
\hline 5.368 & 0.514 & 1.617 & 0.898 & 2.234 & 5 \\
\hline 4.863 & 0.760 & 1.814 & 0.657 & 2.358 & 6 \\
\hline 5.013 & 0.514 & 1.617 & 0.931 & 2.209 & 7 \\
\hline 4.586 & 0.760 & 1.814 & 0.814 & 2.382 & 8 \\
\hline
\end{tabular}




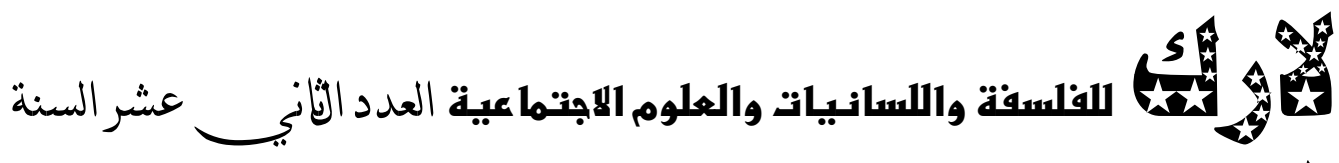

الخامسة2013

\begin{tabular}{|c|c|c|c|c|c|}
\hline 3.776 & 0.521 & 1.419 & 0.748 & 1.802 & 9 \\
\hline 5.632 & 0.633 & 1.543 & 0.929 & 2.246 & 10 \\
\hline 9.113 & 0.521 & 1.419 & 0.721 & 2.321 & 11 \\
\hline 2.871 & 0.642 & 2.012 & 0.774 & 2.333 & 12 \\
\hline 3.213 & 0.514 & 1.617 & 0.901 & 1.987 & 13 \\
\hline 5.521 & 0.760 & 1.814 & 0.563 & 2.395 & 14 \\
\hline 3.776 & 0.521 & 1.419 & 0.748 & 1.802 & 15 \\
\hline 2.270 & 0.760 & 1.814 & 0.830 & 2.098 & 16 \\
\hline 3.991 & 0.514 & 1.617 & 0.923 & 2.086 & 17 \\
\hline 3.301 & 0.760 & 1.814 & 0.855 & 2.234 & 18 \\
\hline 6.372 & 0.521 & 1.419 & 0.632 & 2.000 & 19 \\
\hline 6.513 & 0.770 & 1.864 & 0.699 & 2.617 & 20 \\
\hline 3.705 & 0.514 & 1.617 & 0.774 & 2.000 & 21 \\
\hline 2.602 & 0.833 & 1.925 & 0.773 & 2.246 & 22 \\
\hline 3.241 & 0.514 & 1.617 & 0.851 & 1.975 & 23 \\
\hline 4.504 & 0.665 & 1.790 & 0.728 & 2.284 & 24 \\
\hline 9.184 & 0.521 & 1.419 & 0.801 & 2.395 & 25 \\
\hline 3.563 & 0.760 & 1.814 & 0.646 & 2.209 & 26 \\
\hline 3.103 & 0.521 & 1.419 & 0.980 & 1.802 & 27 \\
\hline 4.358 & 0.760 & 1.814 & 0.641 & 2.296 & 28 \\
\hline
\end{tabular}




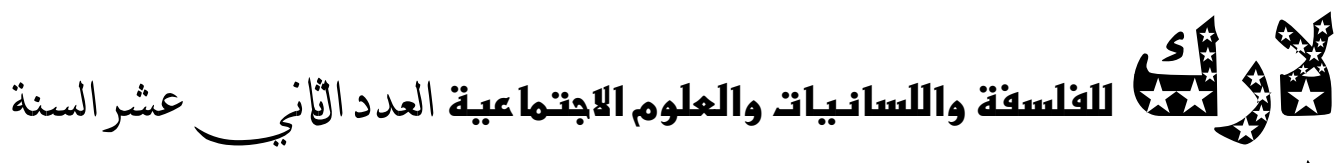

الخامسة2013

\begin{tabular}{|c|c|c|c|c|c|}
\hline 4.398 & 0.7521 & 1.419 & 0.806 & 1.888 & 29 \\
\hline 3.999 & 0.711 & 1765 & 0.741 & 2.222 & 30 \\
\hline 5.782 & 0.521 & 1.419 & 0.538 & 1.901 & 31 \\
\hline 3.974 & 0.760 & 1.814 & 0.781 & 2.296 & 32 \\
\hline 4.965 & 0.521 & 1.419 & 0.700 & 1.901 & 33 \\
\hline 2.975 & 0.642 & 2.012 & 0.872 & 2.370 & 34 \\
\hline 3.568 & 0.521 & 1.419 & 0.812 & 1.802 & 35 \\
\hline 5.480 & 0.654 & 1.506 & 0.692 & 2.086 & 36 \\
\hline 5.428 & 0.741 & 1.666 & 0.547 & 2.222 & 37 \\
\hline 3.228 & 0.760 & 1.814 & 0.748 & 2.197 & 38 \\
\hline 8.410 & 0.744 & 1.654 & 0.503 & 2.493 & 39 \\
\hline 4.006 & 0.760 & 1.814 & 0.689 & 2.271 & 40 \\
\hline 7.674 & 0.521 & 1.419 & 0.748 & 2.197 & 41 \\
\hline 2.270 & 0.760 & 1.814 & 0.830 & 2.098 & 42 \\
\hline 4.332 & 0.521 & 1.419 & 0.600 & 1.802 & 43 \\
\hline 3.089 & 0.670 & 1.888 & 0.798 & 2.246 & 44 \\
\hline 4.226 & 0.514 & 1.617 & 0.632 & 2.000 & 45 \\
\hline 2.270 & 0.760 & 1.814 & 0.830 & 2.098 & 46 \\
\hline 4.557 & 0.514 & 1.617 & 0.800 & 2.098 & 47 \\
\hline 4.355 & 0.760 & 1.814 & 0.826 & 2.358 & 48 \\
\hline
\end{tabular}




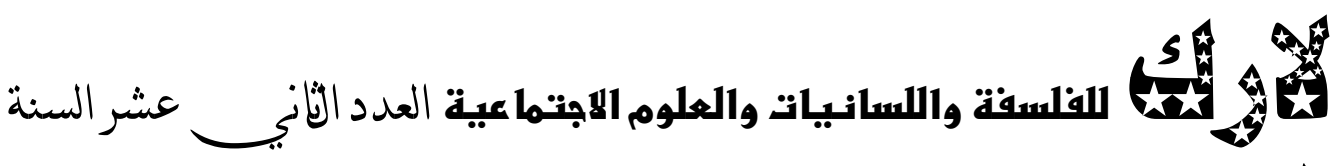

الخامسة2013

\begin{tabular}{|c|c|c|c|c|c|}
\hline 3.678 & 0.521 & 1.419 & 0.459 & 1.703 & 49 \\
\hline 5.398 & 0.727 & 1.654 & 0.637 & 2.234 & 50 \\
\hline
\end{tabular}

ب - صدق الفقرات (معامل الاتساق الداخلي) :

يعد أسلوب علاقة درجة الفقرة بدرجة إجابات الفرد الكلية عن المقياس من المؤشر ات

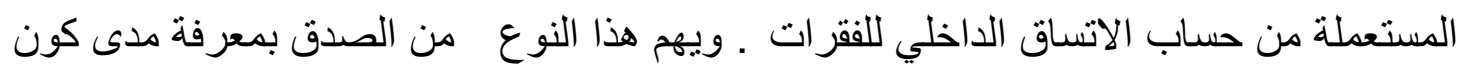

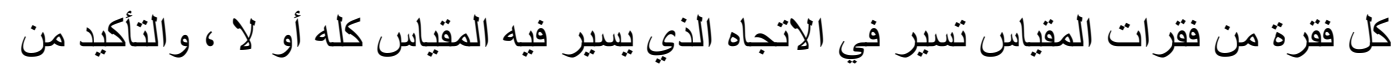
تجانس فقر اته في قياس الظاهرة.

ويعد هذا الإجر اء مكملا للقوة التمييزية ويتحدد من خلال حساب العلاقة الارتباطية بين

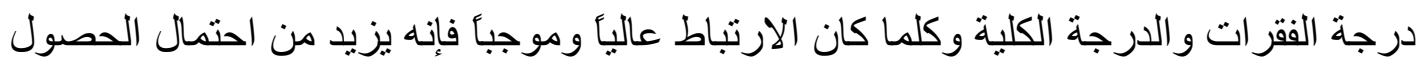

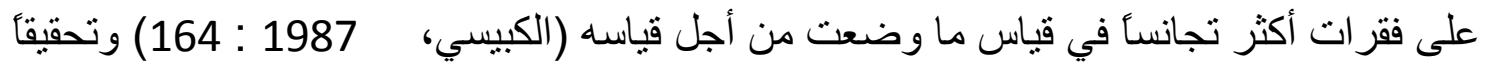

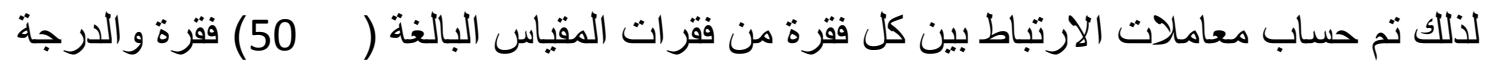
الكلية للمقياس كما مبين في الجدول ( 3) وكانت جميع معاملات الارتباط دالة إحصائيً عند

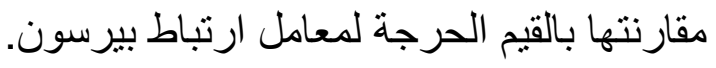

(3) جدول

معاملات ارتباط درجة الفقرة بالدرجة الكلية لمقياس السلوك العدواني لاى طلبة المرحلة الإعدادية

\begin{tabular}{|c|c|c|c|}
\hline معامل الارتباط & الفقرة & معامل الارتباط & الفقرة \\
\hline 0.344 & 26 & 0.172 & 1 \\
\hline 0.238 & 27 & 0.226 & 2 \\
\hline 0.520 & 28 & 0.197 & 3 \\
\hline 0.181 & 29 & 0.250 & 4 \\
\hline 0.256 & 30 & 0.463 & 5 \\
\hline
\end{tabular}




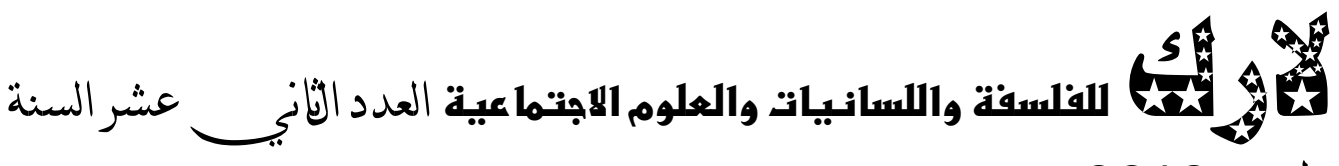
الخامسة2013

\begin{tabular}{|c|c|c|c|}
\hline 0.417 & 31 & 0.388 & 6 \\
\hline 0.211 & 32 & 0.307 & 7 \\
\hline 0.468 & 33 & 0.239 & 8 \\
\hline 0.207 & 34 & 0.406 & 9 \\
\hline 0.451 & 35 & 0.336 & 10 \\
\hline 0.513 & 36 & 0.423 & 11 \\
\hline 0.244 & 37 & 0.614 & 12 \\
\hline 0.418 & 38 & 0.180 & 13 \\
\hline 0.521 & 39 & 0.497 & 14 \\
\hline 0.190 & 40 & 0.499 & 15 \\
\hline 0.306 & 41 & 0.463 & 16 \\
\hline 0.195 & 42 & 0.302 & 17 \\
\hline 0.421 & 43 & 0.160 & 18 \\
\hline 0.451 & 44 & 0.482 & 19 \\
\hline 0.384 & 45 & 0.218 & 20 \\
\hline 0.362 & 46 & 0.451 & 21 \\
\hline 0.536 & 47 & 0.878 & 22 \\
\hline 0.274 & 48 & 0.767 & 23 \\
\hline 0.449 & 49 & 0.226 & 24 \\
\hline 0.302 & 50 & 0.403 & 25 \\
\hline
\end{tabular}

القيمة التائية الجدولية بدرجة حرية (298) : 


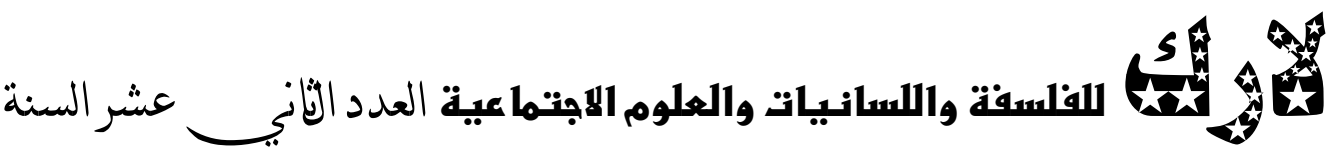

$$
\begin{aligned}
& \text { - عند مستوى دلالة (0.05) = } 0.113 \text { (0.05) = } \\
& \text { - عند مستوى دلالة (0.05) = } 0.148 \text { (0.05) = }
\end{aligned}
$$

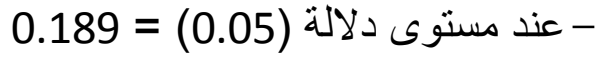

ملاحظة : القوة التميزية للفقر ات وأرتباط الفقرة بالارجة الكلية، كلاهما بعد أن مؤشر ان على (صدق البناء). (صنزة)

الثبات :

يعد الثبات من خصائص المقياس الجيد، ويشير اتساق الدرجات التي جمعت من الأفراد أنفسهم عندما بعاد تطبيق المقياس عليهم مرة أخرى، أو تمت ظروف متغيرة أخرى(عودة، 1992

$$
\text { وقد تم حساب الثبات . }
$$

أ - إعادة الاختبار Test-Retest

يكثف الثبات بطريقة الإعادة عن استقرار النتائج التي يقدمها الاختبار أو المقياس عبر

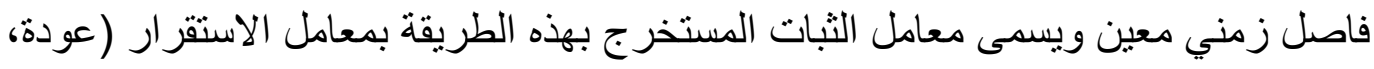
1992 : 195) وقد تم حساب معامل الثبات بإعادة التطبيق بعد مرور ( 14) يومأ من التطبيق الأول على عينة بلغت (60) طالباً وطالبة وقد بلغ معامل الثبات بهذه الطريقة (0.791).

ب - طريقة تحليل التباين باستخدام معادلة ألفا ـ كرونباخ :

تعد هذه الطريقة من حساب الثبات من الطر ائق التي تعبر عن اتساق أداء الفرد على القياس من فقرة الى أخرى، وهو يؤشر الاتساق الداخلي للفقرات ويعبر عن قوة الارتباط بين الفين فقرات المقياس (عودة، 1992 : 195). وبلغ معامل الثبات المسحوسب بهذه الطريقة (0.816). 
الخا مسة 2013

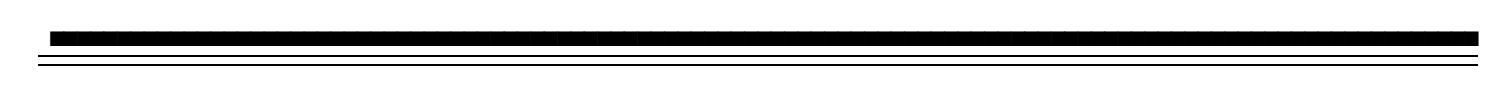

عرض نتائج البحث وتفسيرها: سيتم في هذا الفصل عرض النتائج التي يتم التوصل إليها ومناقثتها بحسب أهداف

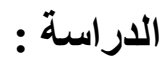

الهلف الأول : تعرف مستوى السلوك العدواني لدى طلبة المرحلة الأعدادية. تم إيجاد الوسط الحسابي والإنحر اف المعياري والقيمة التائية المحسوبة والجدولية كما مبين في

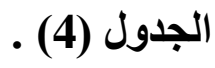

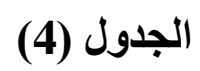

نتائج الاختبار التائي ليعنة واحدة لتعرف مستوى السلوك العدواني لدى طلبة المرحلة الأعدادية

\begin{tabular}{|c|c|c|c|c|c|c|c|c|}
\hline \multirow{2}{*}{ الحكم } & \multirow{2}{*}{ مستوى } & \multicolumn{2}{|c|}{ القيمة التنائية } & \multirow{2}{*}{ الفرضي } & \multirow{2}{*}{ درجة الحرية } & \multirow{2}{*}{ المعياري } & \multirow{2}{*}{ الحسابي } & \multirow{2}{*}{ العدد } \\
\hline & & الجدولية & الحسوبة & & & & & \\
\hline دالة لصالح & & & & & & & & \\
\hline للعينة & 0.05 & 1.960 & 15.446 & 100 & 299 & 11.093 & 84.893 & 300 \\
\hline
\end{tabular}

يتضح من الجدول ( ( 4) أن هناك مستوى عالِ من السلوك العدواني لدى طلبة المرحلة

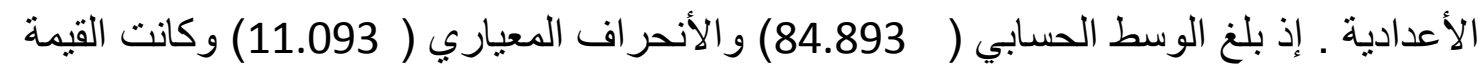

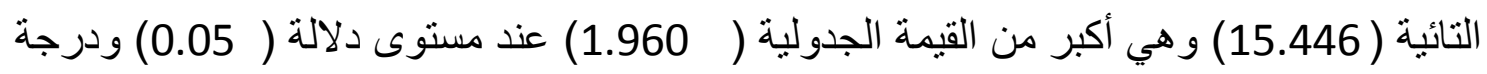
حرية (299) . (15.4)

ويعزو الباحثان أن ارتفاع مسنوى السلوك العدو اني لدى طلبة المرحلة هذه المرحلة

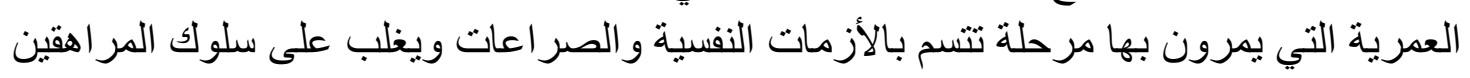

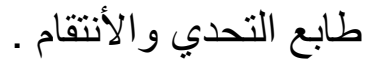




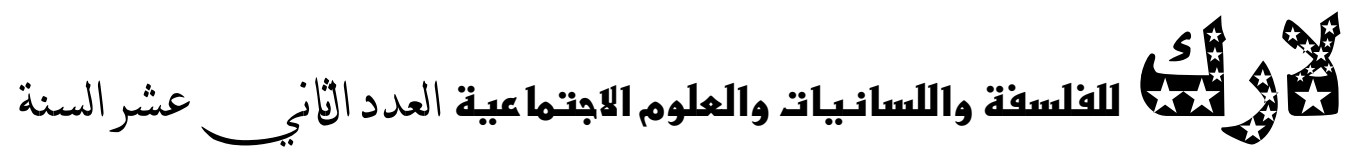
الخامسة2013

و تثبير الأدبيات أن المر اهق يغضب عندما يظلمه الأهل و الرفاق و المدرسون ويغضب

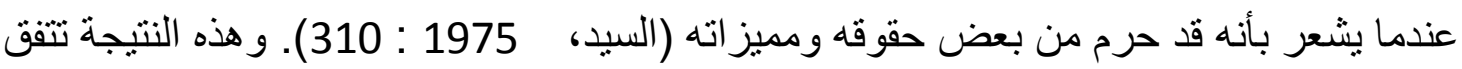
مع در اسة (مونوز وآخرون)(Munozet at ,2007)و تختلف مع در اسة (الفتلاوي، 2010). الهدف الثاني :تعرف دلالة الفروق في مستوى السلوك العدواني لاى طلبة المرحلة الإعدادية تبعاً لمتغير الجنس (ذكور، إناث).

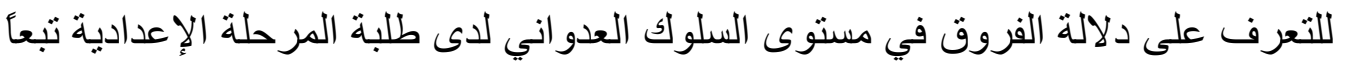
لمتغير الجنس ثم إيجاد المتوسطات الحسابية والانحر افات المعيارية والقيمة التائية المحسوبة الإية

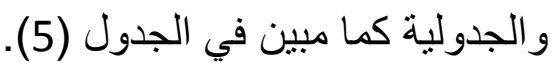

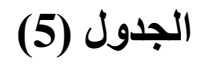

نتائج الاختبار التائي لعينتين مستقلتين لتعرف دلاكة الفروق في مستوى السلوك العدواني لاى الدا

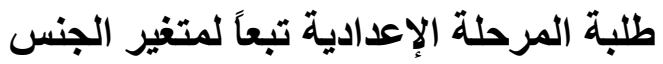

\begin{tabular}{|c|c|c|c|c|c|c|c|c|}
\hline \multirow{2}{*}{ الحكم } & \multirow{2}{*}{ الدلالة } & \multicolumn{2}{|c|}{ القيمة التائية } & \multirow{2}{*}{ درجة الحرية } & \multirow{2}{*}{ الانحر اف } & \multirow{2}{*}{ الحسابي } & \multirow{2}{*}{ العدد } & \multirow{2}{*}{ الجنس } \\
\hline & & الجدولية & المحسوبة & & & & & \\
\hline \multirow{2}{*}{ غير دالة } & \multirow{2}{*}{0.05} & \multirow{2}{*}{1.960} & \multirow{2}{*}{1.048} & 298 & 14.255 & 83.809 & 152 & الذكور \\
\hline & & & & 298 & 10.981 & 85.351 & 148 & الأناث \\
\hline
\end{tabular}

يتضح من الجدول ( 5) أن النتيجة نتير الى عدم وجود فروق ذات دلالة إحصائية بين

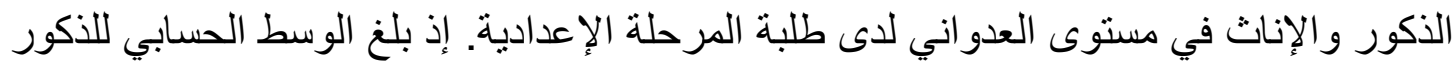

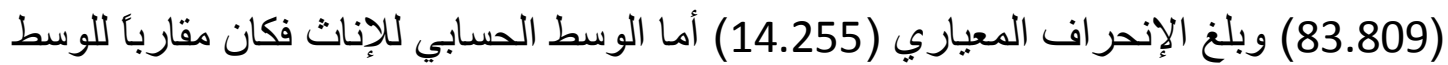
الحسابي للاكور حيث بلغ ( 85.351) وبأنحر اف معياري قدره ( 14:981) (10.981) وكانت القيمة التائية المحسوبة (1.048) و هي أقل من القيمة الجدولية ( حرية (298).

ويرى الباحثان أن هذه النتيجة طبيعية لأن كلا الجنسين يمرون في الظروف نفسها

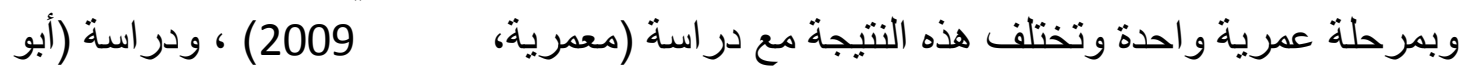
مصطفى و السميري، 2007) ودر اسة (الفتلاوي، 2010) ودر اسة (الثمري، دئ درئ 2003). 


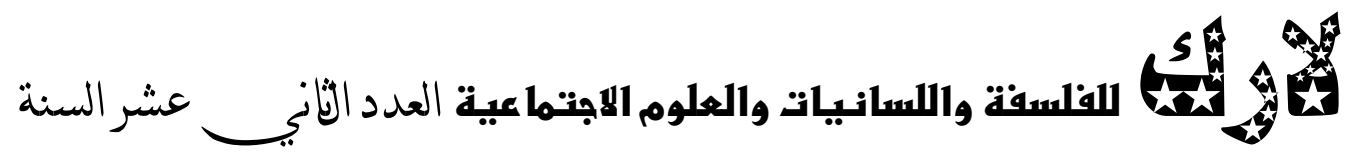
الخامسة2013

الهدف الثالث: تعرف دلالة الفروق في مستوى السلوك العدواني لاى طلبة المرحلة الإعدادية تبعاً لمتغير التخصص (علمي، أدبي) :

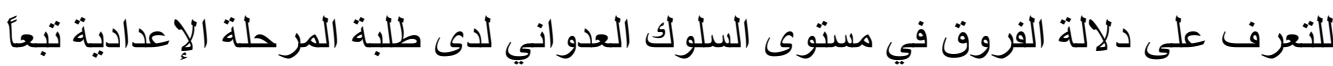

للمتغير التخصص تم إيجاد الوسط الحسابي و الانحر اف المعياري لكل منهما والقيمة التائية

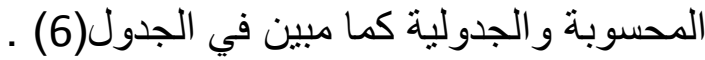

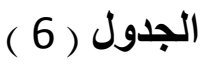

نتائج الاختبار التائي لعينتين مستقلتين لتعرف دلالة الفروق في مستوى السلوك العدواني لدى طلبة المرحلة الإعدادية تبعاً لمتغير التخصص ملالهين (علمي ، أدبي)

\begin{tabular}{|c|c|c|c|c|c|c|c|c|}
\hline \multirow{2}{*}{ الحكم } & \multirow{2}{*}{ الدلالة } & \multicolumn{2}{|c|}{ القيمة التائية } & \multirow{2}{*}{ درجة الحرية } & \multirow{2}{*}{ المعياري } & \multirow{2}{*}{ الحسابي } & \multirow{2}{*}{ العدد } & \multirow{2}{*}{ الجنس } \\
\hline & & الجدولية & المحسوبة & & & & & \\
\hline \multirow{2}{*}{ التخصص التصالح } & \multirow{2}{*}{0.05} & \multirow{2}{*}{1.960} & \multirow{2}{*}{3.025} & 298 & 12.033 & 82.373 & 150 & علمي \\
\hline & & & & 298 & 13.099 & 86.766 & 150 & أدبي \\
\hline
\end{tabular}

يتضح من الجدول (6) أن طلبة التخصص الأدبي هم أعلى مستوى في السلوك العدواني

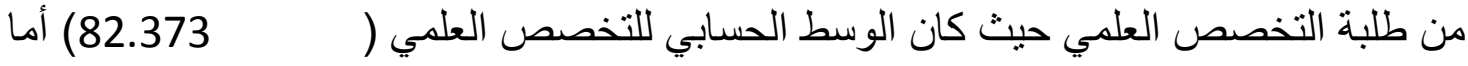
الانحر اف المعياري فكان (12.032) و هو أقل من الوسط الحسابي لطلبة التخصص الأدبي البالغ (86.766) وبانحر اف معياري قدرة (13.099) عند مستوى دلالة ( 0.05) ودرجة حرية ( 298) و هذه النتيجة دالة لصالح التخرصال التصص الادبي.

ويرى الباحثان أن السبب قد يعود الى النظرة التي يحملها طلبة التخصص الأدبي على أن

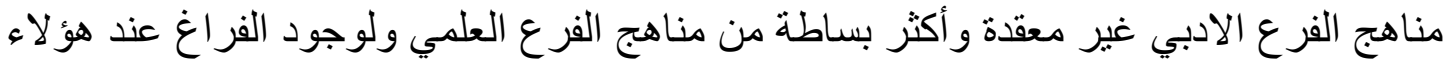

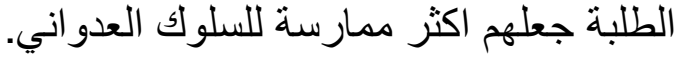

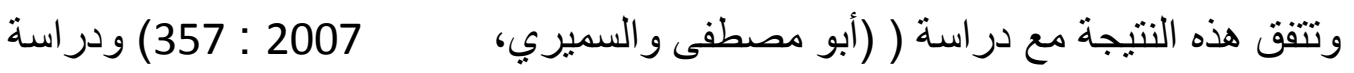


الخامسة

الاستنتاجات :

فيما يلي عرض موجز للاستتناجات التي توصل إليها الباحث :

1 - أثنارت نتائج الهدف الأول الى أن هناك مستوى عالي من السلوك العدواني لدى طلبة المرحلة الإعداديبة.

2 - أما نتائج الهدف الثاني فقد أثارت الى عدم وجود فروق ذات دلالة إحصائية في مستوى الإن السلوك العدو اني بين الذكور و الاناث.

3 - أما نتائج الهدف الثالث فقد أشارت وجود فروق ذات دلالة إحصائية بين التخصص الأدبي

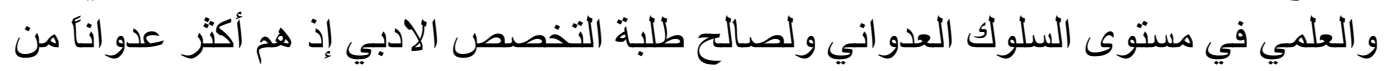

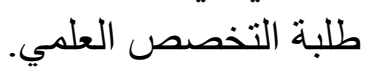

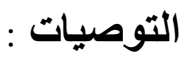

1 - زيادة الاهتمام بمرحلة المر اهقة إذ يؤكد علماء النفس على أن هذه المرحلة إذا لم تكتنفها

الرعاية و التنشئة الصالحة تعد من أكثر المر احل التي يتو افر فيها كل مقومات إنهاء إظهار

العدوان و العنف. العه وان.

2 - ضرورة تو افر الجو النفسي المناسب داخل المدرسة لكي نحصل على تغييرات ضرورية وبناءه.

3 - التصدي لمشاكل الطلبة و إيجاد الحلول المناسبة لها. 


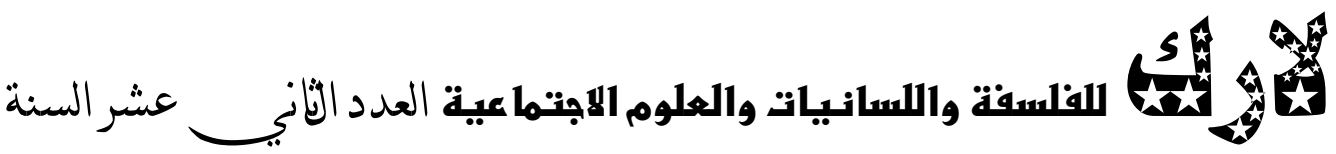
الخامسة2013

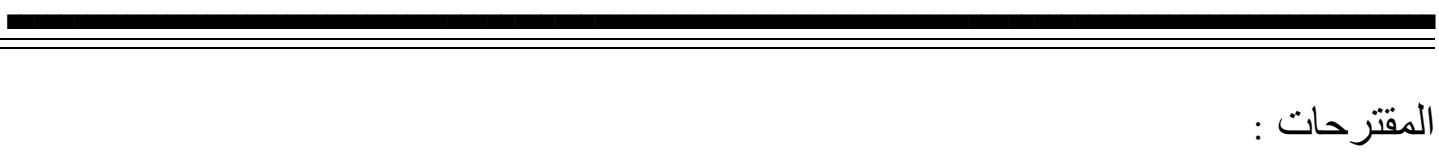

إجر اء در اسات مماثلة لعينات طلابية أخرى لاسيما مرحلة الابتدائية و المتوسطة و الجامعة . 
الخامسة

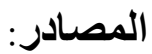

1 - ابر اهيم ، ريكان (1987) : النفس والعدوان ، بغداد ، آفاق عربية.

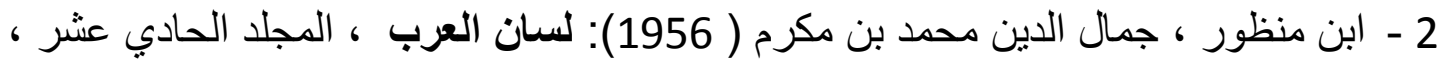
لبنان ، دار بيروت للطباعة.

3 - أبو قوره ، خليل قطب(1996): سيكولوجية العدوان ، القاهرة ، مكتبة الانجلو المصرية. 4 - أبو مصطفى ، نظمي عوده و السميري نجاح عو اد (

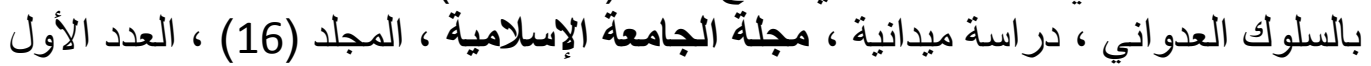

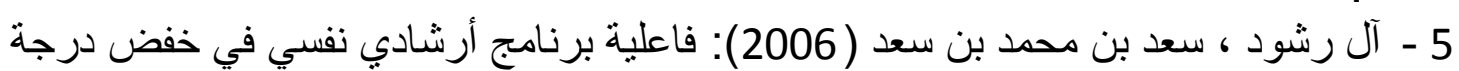

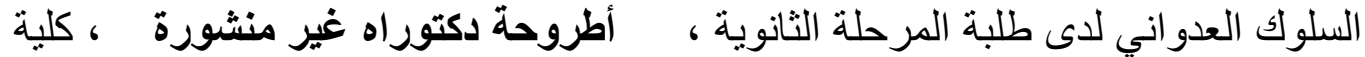

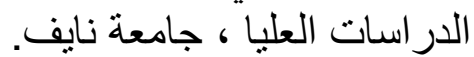

6 - بطرس ، حافظ بطرس (2008): المشكلات النفسية وعلاجها ، ط1 ، عمان ، دار المسيرة للنشر و التوزيع و الطباعة.

7 - دافيدوف ، لندال ( 1983) : مدخل علم النفس ، ط 3 ، ترجمة : سيد طو اب وآخرون

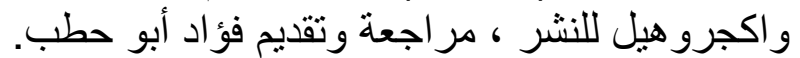

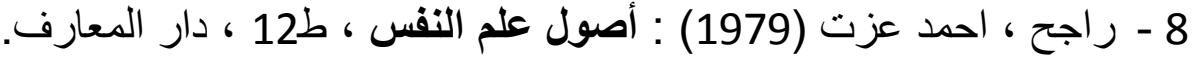

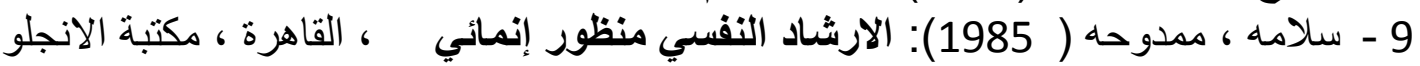

10 الثمري ، أحلام جبار عبد الله(2003): السلوك العدواني لدى طلبة المرحلة المتوسطة في مئي

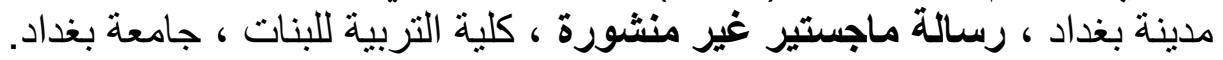

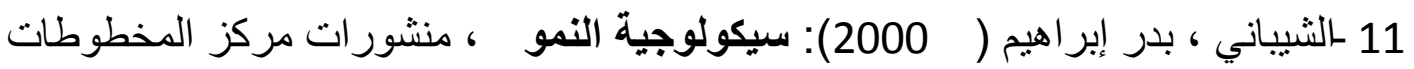

12 - العقاد ، عصام عبد اللطيف ( ) الكويت.

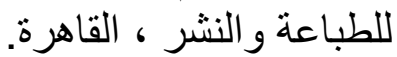

13 -العيسوي ، عبد الرحمن ( 1984) : سيكولوجية الجنوح ، دار النهضة العربية للطباعة ،

بيروت ، لبنان.

14 ـالعيسوي ، عبد الرحمن (2007) : سيكولوجية العنف المدرسي والمشاكل السلوكية .

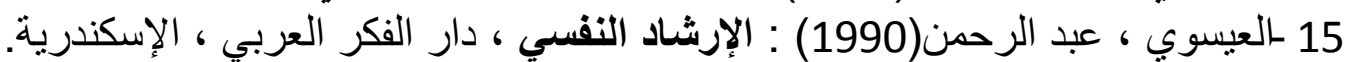

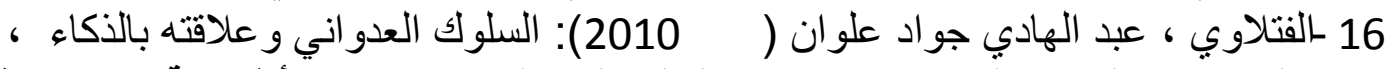

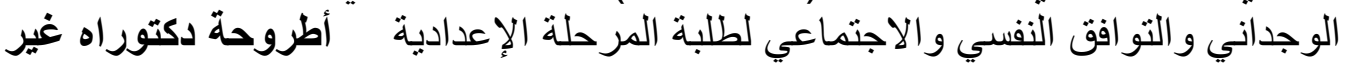
منشورة ، كلية - ابن رشد ، جامعة بغداد.

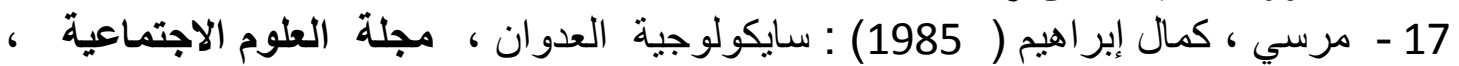
العدد 2 ، الكويت. 
18 معمرية ، بشير (2009) : در اسات نفسية حول طلاب المدارس و الجامعات وفئات اخرى

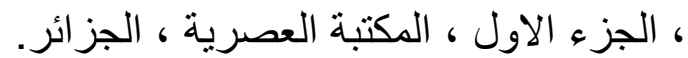

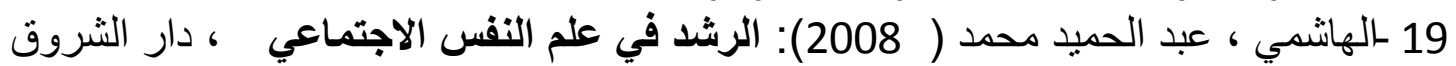
للنشر و التوزيع و الطباعة ، جدة.

20- Micheal , S , et al (1971) : childhood behavior and mental helth . London, Vniversity of London press.

21- Har Krerg .M.C(1994) : " The New We bsters Inter national Encvlop Edia " Florida Trident press In temational.

22- Ellis .A(1976) : Rationl emotive theorg in banister (ed) issues and approaches in the psgchological therapies, New York.

23- Muno2, et al (2007) : Physical and psycholo gical aggression in dating relationship in spnish university students, psicothema ', Vol 19 No . 1 , pp 102-107.

24- Biswas p , (1989) : Drection of Aggression on of School - Going Adoles Cents Related to Family Tension : Area of Residence and sex : Acoparative Study, in : Manas, Vol , 36 (1-2). 
كُش

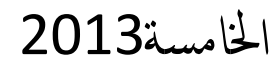

بسم الله الرمن الرحيم

جامعة واسط

كلية التربية

قسم العلوم النفسية والثربوية

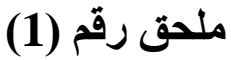

آراء الخبراء في مدى صدق الفقرات السلوك العدواني

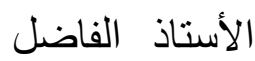

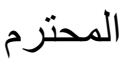

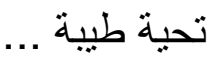

يروم الباحثن القيام بدراسة بعنوان(السلوك العدواني لاى طلبة المرحلة الإعدادية ) ولقياس

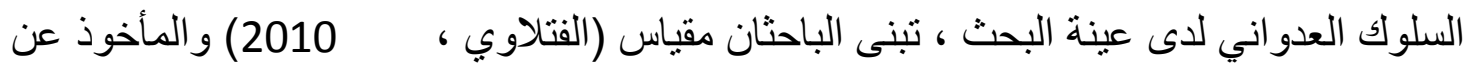

(باظة ،2003) المعد للمر اهقين و الذي تكون من (52) فقرة لقياس السلوك العدو اني.

لقد عُرف السلوك العدواني بأنه (إيقاع الأذى والضرر بالآخرين أو الذات ويتم التعبير عنه

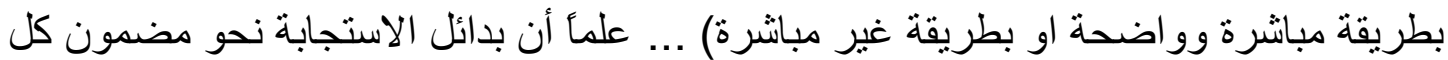

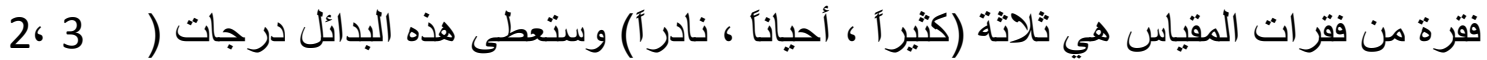

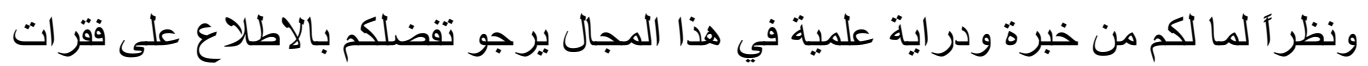

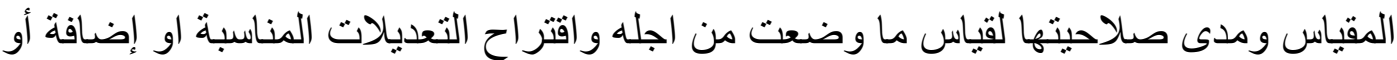
حذف فقرات أو دمجها على وفق ما ترونه مناسباً. ولكم خالص الثكر وفائق الاحترام لتعاونكم العلمي معن 


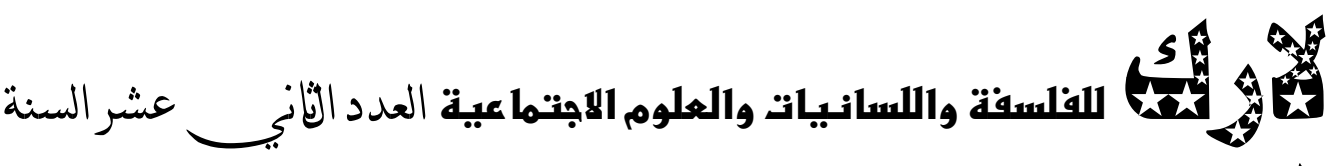

الخامسة2013

\section{الباحثان}

صبري عبد الله كاظم الركابي

أ.د. جعفر عبد الكاظم المياحي

\section{همقت(1)}

أسمهاء الخبراء والمكمين على أداة البحث

\begin{tabular}{|c|c|c|c|}
\hline 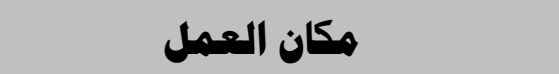 & التغصص العلهمي & اسم الخبـير & 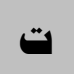 \\
\hline كلية التربية - ابن رشد - جامعة بغداد & علم النفس التربوي & أ.د. عبد الأمبر عبود شمسي & .1 \\
\hline كلية التربية للبنات - جامعة بغداد & إرشـاد نفسي & أ.د. شاكر مبدر جاسم & .2 \\
\hline كلية الآداب - جامعة واسط & علم النفس الاجتماعي & أ.د. يوسف عناد العائدي & .3 \\
\hline كلية التربية - ابن رشد - جامعة بغداد & القياس و التقويم & أ.م.د. محمد أنور السامر ائي & .4 \\
\hline كلية التربية- جامعة و اسط & علم النفس التعليمي & أ.م.د.تحسين حسين علي & .5 \\
\hline كلية التربية- جامعة و اسط & طر ائق تدريس العلوم & أ.م.د. مهدي حطاب سخي & 6 \\
\hline كلية الآداب - جامعة واسط & إرشـاد نفسي & أ.م.د. أسعد شريف الاماره & .7 \\
\hline كلية التربيةــ الجامعة المستتصرية & علم النفس التربوي & أ.م.د. لمياء ياسين الركابي & .8 \\
\hline كلية الآداب - جامعة بغداد & علم النفس التربوي & أ.م.د. ابر اهيم مرتضى الاعرجي & .9 \\
\hline كلية التربية للبنات - جامعة بغداد & علم نفس النمو & أ.م.د. طالب ناصر حسين القيسي & .10 \\
\hline
\end{tabular}


الخا مسنة

\section{هلمق رقم (2)}

هقياس السلوك العدواني بصيغته الأولية

\begin{tabular}{|c|c|c|c|c|}
\hline تنطبق علي نادراً & تنطبق علي احياناً & تنطبق علي & 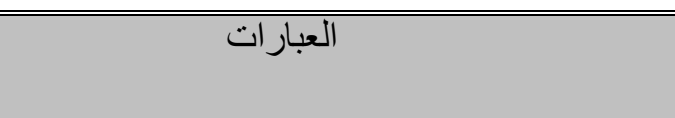 & ت \\
\hline & & & أسيء للمحيطين لي بألفاظ نابية عندما اختلف معهم. & 1 \\
\hline & & & يصفني زملائي الطلبة باني مجادل . . & 2 \\
\hline & & & اعبر عن رأيي دون مر اعاة مشاعر الآخرين. & 3 \\
\hline & & & لا أر اعي شُور المحيطين بي في تعبيراتي اللفظية & 4 \\
\hline & & & أميل للسخرية من آراء الآخرين . . & 5 \\
\hline & & & استطيع أَثارة زملائي الطلبة لفظياً. . & 6 \\
\hline & & & عندما اختلف مع أصدقائي اخبر الجميع بأخطائهم . & 7 \\
\hline & & & إن مبدئي في الحباة ردّ الاهانة بالمثل . . & 8 \\
\hline & & & كثير أ ما اذكر الآخرين بأخطائهم علنياً. . & 9 \\
\hline & & & أسيء لفظياً للآخرين بدون عذر مقتع . & 10 \\
\hline & & & لا أعطي الفرصة لغيري في الحديث و الحوار . & 11 \\
\hline & & & عندما يضايقني أي فرد اخبره بما انقده في شخصده. & 12 \\
\hline & & & أكون قاسيا في الحديث مع أفر اد أسرتي . & 13 \\
\hline & & & إذا أثنارني احد لا أتردد في ضربه. & 14 \\
\hline & & & أرد الإساءة البدنية بأقوى منها . & 15 \\
\hline & & & اشعر بالاندفاع نحو أتناف ممنلكات الآخرين . & 16 \\
\hline & & & أَشارك في المشاجر ات بدون سبب . & 17 \\
\hline
\end{tabular}


كلغة الخامس2013

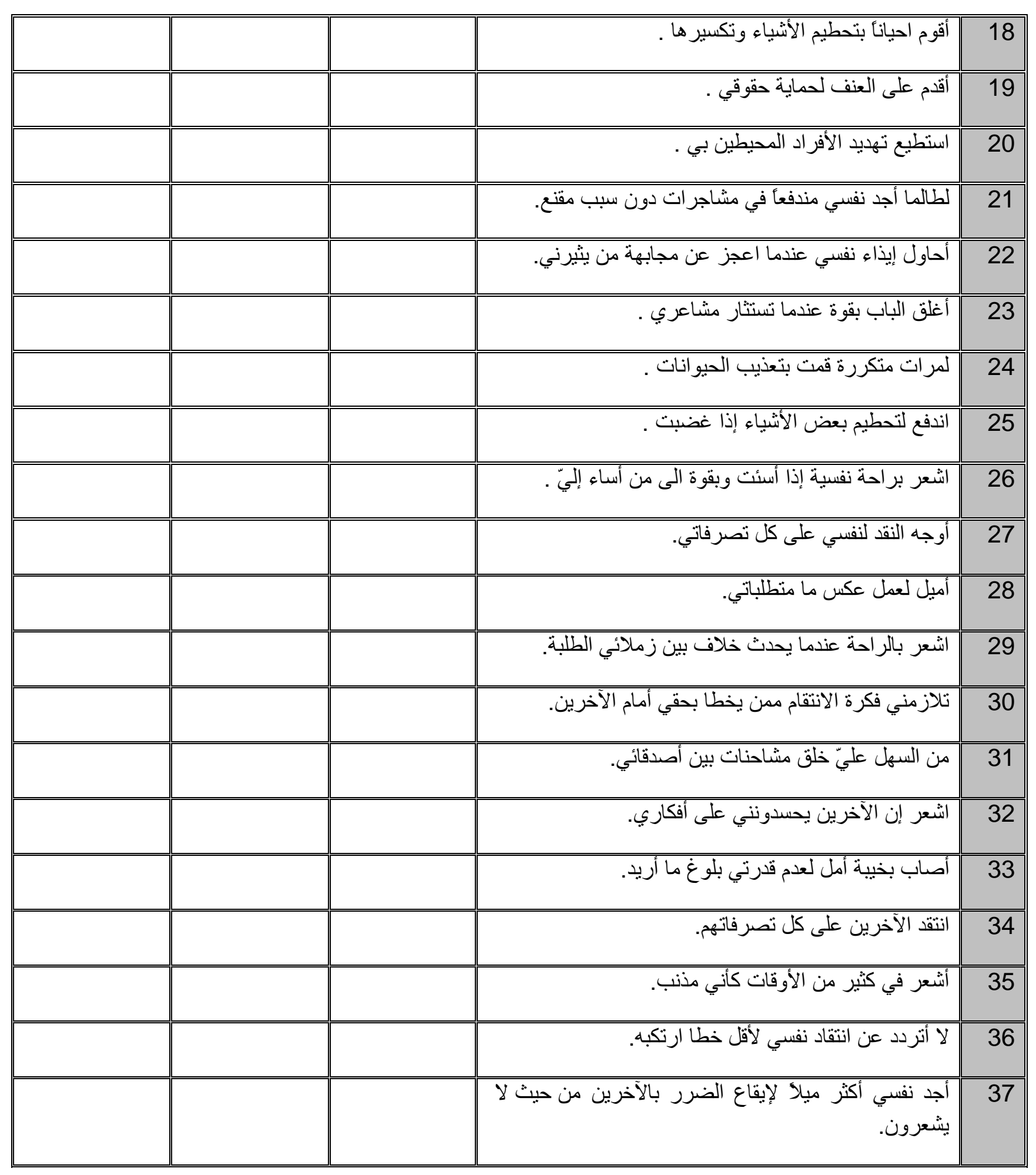




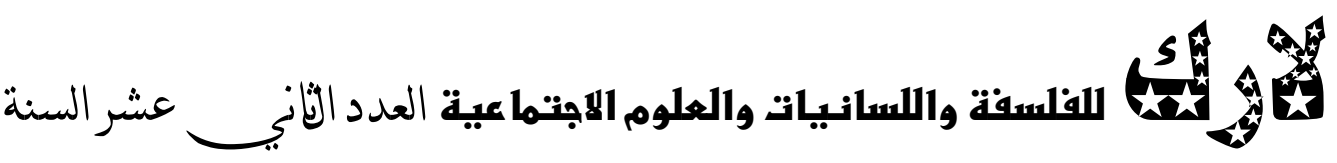
الخامسة2013

\begin{tabular}{|c|c|c|c|c|}
\hline & & & اشعر بالسعادة عند مشاهدة قتال بين الحيو انات. & 38 \\
\hline & & & اشعر وكان الناس يدبرون المكائد لي من وراء ظهري. & 39 \\
\hline & & & اشعر أنني شخص متقلب المز اج. & 40 \\
\hline & & & اغضب بسر عة إذا ضايقني أب فرد. & 41 \\
\hline & & & أتضايق كثير أ من عادات المحيطين بي. & 42 \\
\hline & & & من الصعب عليّ ضبط مز اجي. & 43 \\
\hline & & & اشعر إن لدي حسلسية شديدة للنقا. & 44 \\
\hline & & & اغضب بسر عة إذا لم يفهمني الآخرون . & 45 \\
\hline & & & اشعر بضيق وكرب في بعض أوقات هدوئي . & 46 \\
\hline & & & أجد صعوبة في التخلص بسهولة مما يؤلمني . & 47 \\
\hline & & & اشعر في بعض الأحيان وكأني على وشك الانفجار. & 48 \\
\hline & & & لا أتحمل أي نقد من الآخرين . & 49 \\
\hline & & & ينفذ صبري بسهولة عند التعامل مع زملائي الطلبة . & 50 \\
\hline & & & ليُغضبني عادات بعض أفراد أسرتي . & 51 \\
\hline & & & تؤذيني أخطاء الآخرين و هفو اتهم. & 52 \\
\hline
\end{tabular}


كاغ الخامسة2013

ملمق رقم (3)

الفقرات المستبعدة هن هقياس السلوك العدواني

\begin{tabular}{|c|c|}
\hline العبار ات & ت \\
\hline لطالما أجد نفسي مندفعاً في مشاجر ات دون سبب مقنع. & 1 \\
\hline أميل لعمل عكس ما منطلباتي. & 2 \\
\hline
\end{tabular}

هلمق رقم (4)

هقياس السلوك العدواني بصيغته النهائية

جامعة و اسط

كلية التربية

قسم العلوم النفسية والثربوية

ذكر

أنثى 


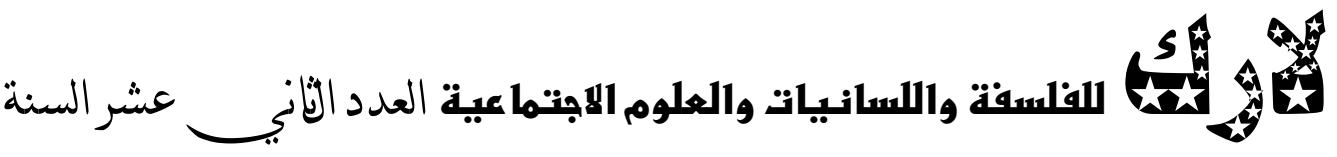
الخامسة2013
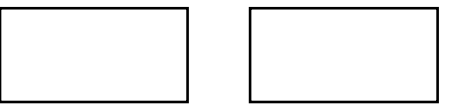

الجنس:

علمي
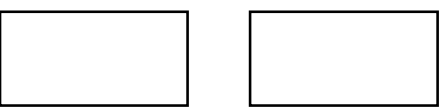

التخصص:

أدبي

عزيزتي الطالبة عزيزي الطالب

أمامك مقياس يتضمن عدد من الفقرات يرجى تعاونك من خلال الإجابة على كل فقرة وتحديد

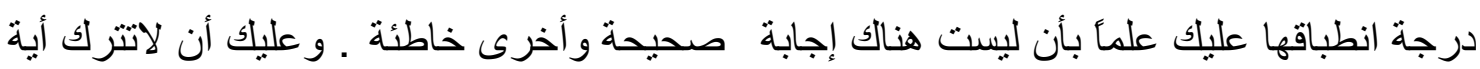

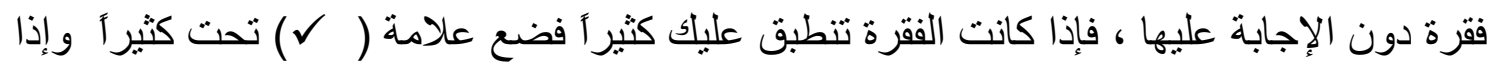

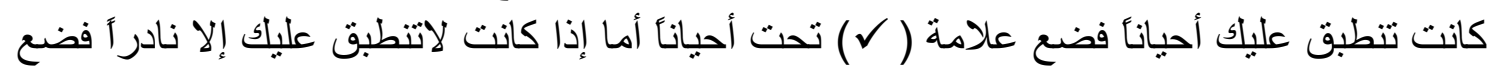

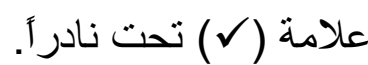
واعلم عزيزي الطالب عزيزتي الطالبة إن إجابتلك لإغر اض البحث العلمي ولن بطلع عليها أحد سوى الباحثان و لا داعي لذكر الاسم مثال توضيحي:

\begin{tabular}{|c|c|c|c|}
\hline تنطبق علي نادر أ & تنطبق علي احياناً & تنطبق علي كثير آ & العبار ات \\
\hline & & & إذا أثارني احد لا أتردد في ضربه. \\
\hline
\end{tabular}

مع خالص الثكر و التقدير لتعاونكم معنا

الباحثان 


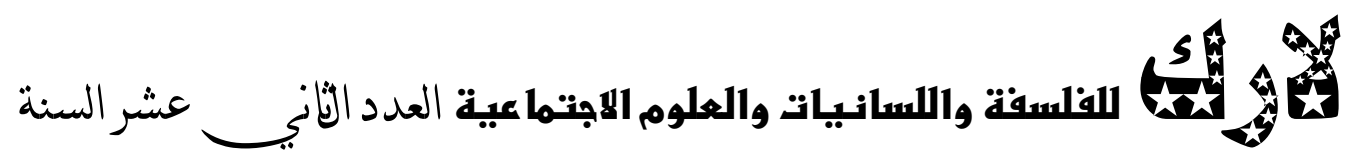
الخامس2013

صبري عبد الله كاظم

أ.د. جعفر عبد الكاظم المياحي

الركابي

\begin{tabular}{|c|c|c|c|c|}
\hline تنطبق & تنطبق علي & تنطبق علي & 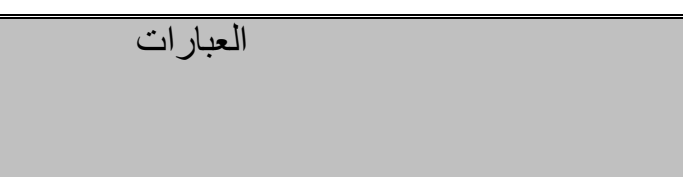 & $ت$ \\
\hline & & & أسيء للمحيطين لي بألفاظ نابية عندما اختلف معهم. & 1 \\
\hline & & & يصفني زملائي الطلبة باني مجادل . . & 2 \\
\hline & & & اعبر عن رأيي دون مر اعاة مشاعر الآخرين. & 3 \\
\hline & & & لا أر اعي شعور المحيطين بي في تعبيراتي اللفظية . & 4 \\
\hline & & & أميل للسخرية من آراء الآخرين . & 5 \\
\hline & & & استطيع أثارة زملاني الطلبة لفظيًا] . & 6 \\
\hline & & & عندما اختلف مع أصدقائي اخبر الجميع بأخطائهم . & 7 \\
\hline & & & إن مبدئي في الحياة ردّ الاهانة بالمثل . & 8 \\
\hline
\end{tabular}


الخا مسنة

\begin{tabular}{|c|c|c|c|c|}
\hline & & & كثير أ ما اذكر الآخرين بأخطائهر علنياً & 9 \\
\hline & & & أسيء لفظياً للآخرين بدون عذر مقنع . & 10 \\
\hline & & & لا أعطي الفرصة لغيري في الحديث والحوار . & 11 \\
\hline & & & عندما يضايقني أي فرد اخبره بما انقده في شخصه. & 12 \\
\hline & & & أكون قاسيا في الحديث مع أفر اد أسرني . & 13 \\
\hline & & & إذا أثنارني احد لا أتردد في ضربه. & 14 \\
\hline & & & أرد الإساءة البدنية بأقوى منها . & 15 \\
\hline & & & اشعر بالاندفاع نحو أتلاف ممتلكات الآخرين . & 16 \\
\hline & & & أششارك في المشاجر ات بدون سبب & 17 \\
\hline & & & أقوم احيانأ بتحطيم الأشياء وتكسير ها & 18 \\
\hline & & & أققد على العنف لحماية حقوقي . & 19 \\
\hline & & & استطيع تهديد الأفراد المحبطين بي . & 20 \\
\hline & & & أحاول إيذاء نفسي عندما اعجز عن مجابهة من يثيرني. & 21 \\
\hline & & & أغلق الباب بقوة عندما تستثار مشاعري . & 22 \\
\hline & & & لمر ات متكررة قمت بتعذيب الحيو انات & 23 \\
\hline & & & اندفع لتحطيم بعض الأشياء إذا غضبت . & 24 \\
\hline & & & اشعر براحة نفسية إذا أسئت وبقوة الى من أساء إليّ . & 25 \\
\hline & & & أوجه النقد لنفسي على كل تصرفاتي. & 26 \\
\hline & & & اشعر بالر احة عندما يحدث خلاف بين زملائي الطلبة. & 27 \\
\hline & & & تلازمني فكرة الانتقام ممن بخطا بحقي أمام الآخرين. & 28 \\
\hline & & & من السهل عليّ خلق مشاحنات بين أصدقائي. & 29 \\
\hline
\end{tabular}




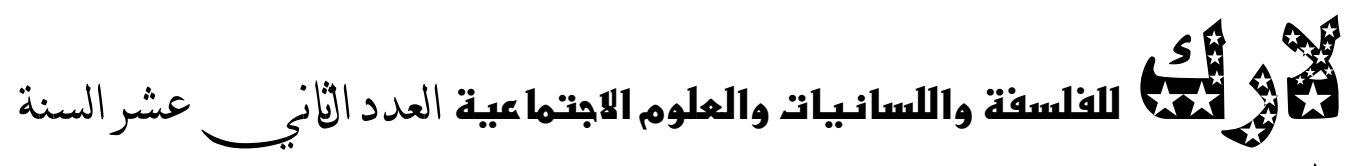
الخامسة2013

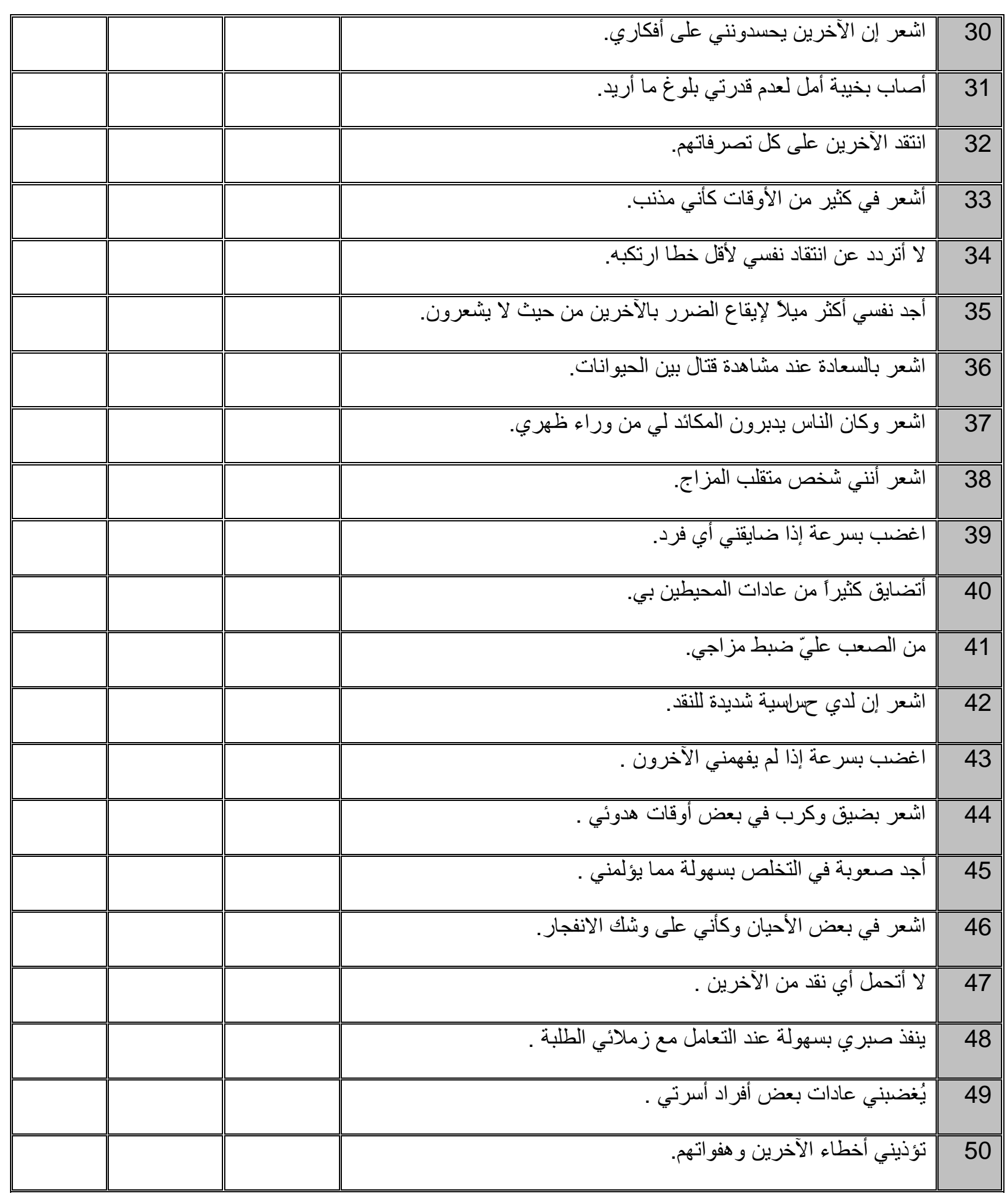




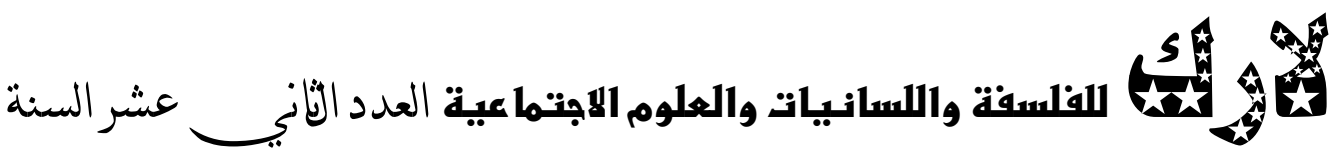
الخامسة2013

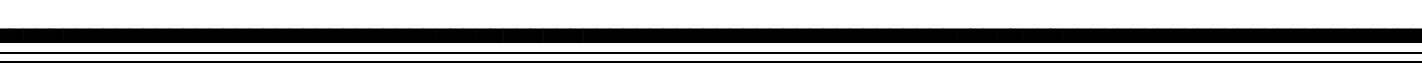

